\title{
Taking real rigidities seriously: implications for optimal policy design in a currency union
}

Citation for published version (APA):

Lieb, L. M. (2009). Taking real rigidities seriously: implications for optimal policy design in a currency union. METEOR, Maastricht University School of Business and Economics. METEOR Research Memorandum No. 032 https://doi.org/10.26481/umamet.2009032

Document status and date:

Published: 01/01/2009

DOI:

10.26481/umamet.2009032

Document Version:

Publisher's PDF, also known as Version of record

\section{Please check the document version of this publication:}

- A submitted manuscript is the version of the article upon submission and before peer-review. There can be important differences between the submitted version and the official published version of record.

People interested in the research are advised to contact the author for the final version of the publication, or visit the DOI to the publisher's website.

- The final author version and the galley proof are versions of the publication after peer review.

- The final published version features the final layout of the paper including the volume, issue and page numbers.

Link to publication

\footnotetext{
General rights rights.

- You may freely distribute the URL identifying the publication in the public portal. please follow below link for the End User Agreement:

www.umlib.nl/taverne-license

Take down policy

If you believe that this document breaches copyright please contact us at:

repository@maastrichtuniversity.nl

providing details and we will investigate your claim.
}

Copyright and moral rights for the publications made accessible in the public portal are retained by the authors and/or other copyright owners and it is a condition of accessing publications that users recognise and abide by the legal requirements associated with these

- Users may download and print one copy of any publication from the public portal for the purpose of private study or research.

- You may not further distribute the material or use it for any profit-making activity or commercial gain

If the publication is distributed under the terms of Article $25 \mathrm{fa}$ of the Dutch Copyright Act, indicated by the "Taverne" license above, 


\section{Maastricht University}

\section{Lenard Lieb}

Taking Real Rigidities Seriously: I mplications for Optimal Policy Design in a Currency Union

RM/09/032

\section{METEOR}

Faculty of Economics and Business Administration Maastricht Research School of Economics

of Technology and Organization

\section{P.O. Box 616}

NL - 6200 MD Maastricht

The Netherlands 


\title{
Taking Real Rigidities Seriously: \\ Implications for Optimal Policy Design in a Currency Union
}

\author{
Lenard Lieb*
}

April 2009

\begin{abstract}
In this paper I analyze optimal monetary and fiscal policy in a monetary union from a union-wide perspective. For this purpose I lay out a New Keynesian business cycle model of a currency union with rigid real wages. The fiscal policy is implemented at the country level through the choice of government spending, while the monetary authority sets a common nominal interest rate. I find that, given these assumptions, in the presence of country-specific as well as in the presence of symmetric shocks to technology there is a country-level trade-off between stabilizing inflation and output relative to its efficient outcome. After a union-wide technology shock also the common monetary authority faces a trade-off. Hence, if the shift to technology is common to all member countries the optimal policy on a union-wide level requires that the common monetary policy reacts slightly countercyclical. This is reversed on the domestic level, where, under the optimal policy, the government purchases stabilize the economy via countercyclical spending, no matter if shocks are symmetric or not. Although not always optimal, I find that strict inflation targeting is very close to the optimal policy in terms of aggregate welfare losses.
\end{abstract}

Keywords: monetary union; inflation inertia; real wage rigidities; countercyclical policy

${ }^{*}$ Maastricht University, Department of Economics, PO Box 616, MD 6200, Maastricht, The Netherlands. Email: L.Lieb@maastrichtuniversity.nl. The author thanks Michael C. Burda, Monique Ebell, Stefan Ried, Bertrand Candelon and Joan Muysken for helpful comments and remarks. Usual disclaimers apply. 


\section{Introduction}

Due to the current economic downturn the public (and academic) debate about monetary policy in the Euro area has flared up again. Although under somewhat political pressure, the European Central Bank (ECB) adheres on its principle of price level stabilization. Compared to their US counterpart, the Federal Reserve System (Fed), the ECB uses monetary policy in order to stabilize the economy only very tentatively. This is in line with some of the cutting-edge models used for monetary policy advice. Strict price level targeting corresponds to the recent emphasis in modeling economies within the New Keynesian (NK) framework on stabilizing the output gap. In this setting there is no trade-off between price stability and stability of output around potential. In the last few years this modeling framework has become very popular as a theoretical basis for policy decisions for western central banks. This dynamic modeling approach assumes imperfect competition in the goods market and sluggish nominal price adjustment. Inspired by a seminal paper of Clarida, Galí and Gertler (1999), a lot of research effort has put into the advancement of these NK theories.

The formation of a monetary union in Europe and the debate about the "Stability and Growth Pact" (SGP) make the analysis of fiscal and monetary interactions an especially interesting topic. It is often argued that the loss of monetary policy flexibility due to the merger of currencies increases the potential role of fiscal policy as a stabilization tool and the need for fiscal policy cooperation within Europe. Thus, to optimally characterize policy in the European Monetary Union (EMU) the fiscal stance has to be taken into account. The interaction of monetary and fiscal policy in a NK modeling framework has been examined for instance by Corsetti and Pesenti (2001) and Schmitt-Grohé and Uribe (2004) (for a closed economy) or by Lombardo and Sutherland (2004) and Leith and Wren-Lewis (2008) (for an open economy).

Given its potential relevance for political decision makers, only a few papers considering monetary and fiscal aspects in a currency union have been written in the last years. Most of the existing literature analyzes monetary and fiscal policy within a micro-founded, two-country sticky-price model of a monetary union (e.g. Beetsma and Jensen, 2005 or Ferrero, 2007 and 2009). Since a two-country approach may be usefull to discuss issues concerning the interaction between two large economies (e.g. the EU and the US), it can only hardly be viewed as a realistic description of a monetary union like the EMU with currently sixteen member states. Just recently, Galí and Monacelli (2008) 
proposed a framework which incorporates the features above mentioned, but comprises many open economies linked by trade and financial flows. Since most of the member states of the EMU are small relative to the union as a whole, domestic policy decisions have very little impact on other member states.

After having been largely ignored by monetary economists for a long time, the importance of real rigidities for monetary policy has received fresh impetus with a recent paper by Blanchard and Galí (2007). They showed that including rigid real wages in a NK business cycle model leads to a notable trade-off between stabilizing the price level and the welfare relevant output. Moreover, as already highlighted in Galí, Gertler and Lopez-Salido (2001), by constituting a channel from wage to inflation dynamics through firms' marginal costs, slow adjustment in wages will translate into more persistent movements in inflation, which is particularly found in European data.

Real wage rigidity, indeed, seems to be an important feature of European labor markets. As found by Apaia and Pichelmann (2007), using micro data from all EMU countries, the half-lives of deviations of the real wages from its equilibrium level are varying between three quarters and three years.

Hence, in the analysis of European-wide monetary and fiscal policy design, real wage rigidity can hardly be neglected. Despite its importance, research in this direction its still in its infancy. Campolmi and Faia (2006) and Arbritti (2007) were the first (and as far as I know still the only) authors including real wage rigidity in a dynamic model of a currency union.

Thus, in my opinion, an analytical framework of the EMU should have the following four properties: It has to rely on the assumptions of standard NK theory (i.e. imperfect competition and nominal rigidities), should include a monetary and fiscal authority, has to comprise many open economies (not only two), and has to incorporate real rigidities.

The model I propose in this paper meets all desiderata listed above. More precisely, I use a version of the Galí and Monacelli (2008) model extended by a partial adjustment process of the real wage. I focus on optimal monetary and fiscal policy from a unionwide perspective. That is, optimal monetary and fiscal policy are derived by maximizing an aggregated (second-order) welfare approximation. More precisely, I assume that both fiscal and monetary authorities implement Ramsey solutions (i.e. an optimal commitment 
strategy).

The main findings of the analysis are as follows. Since I assume that a single member country has very little impact on union-wide economic conditions, an idiosyncratic shock does not affect union-wide economic dynamics. Hence, the common central bank has no need to intervene. However, if each member country is affected by a shock (or they are not idiosyncratic), the common central bank faces a trade-off between stabilizing the price level and the welfare relevant output. Because of the complexity of the tarheting rule, an optimal policy is hard to implement, when possible at all. However, I find that strict inflation targeting is close to the optimal policy (in terms of welfare losses), and thus can be seen as a "second best" option which is easy to implement by the common central bank. The optimal union-wide monetary policy, however, is conditional on the fiscal policies implemented optimally by domestic fiscal authorities. Additionally to the findings of Galí and Monacelli (2008), I find that optimal domestic fiscal policy plays a national stabilization role also if shocks are symmetric. The quantitative simulations show that the strength of countercyclical public spending increases with the importance of nominal and real rigidities. Since optimal domestic fiscal policy has an important stabilization role - also from a union-wide perspective - external constraints like the SGP should be questioned, or at least reconsidered.

Moreover, I find that real wage rigidity indeed provides a rational for a more inertial inflation dynamics. The New Keynesian Phillips Curve derived here has a noticable similarity to a "hybrid" version recently used in the literature for empirical investigation on inflation dynamics.

The remainder of this paper is as follows: Section two describes related literature. The underlying model is outlined in section three. Next, I examine an important benchmark of the model: the pareto efficient allocation. Then a short overview of the implementation method is given and the baseline calibration of the model is presented. The results of the analysis are reported in section six. Section seven concludes.

\section{Related Literature}

An extensive amount of work has been done on monetary policy in micro-founded models with sticky prices. Also the interaction between monetary and fiscal policy in such a framework has been analyzed in recent years (e.g. Schmidt-Grohe and Uribe, 2004 or 
Leith and Wren-Lewis, 2008). Although it has become acutely important with the creation of the EMU, multi-country versions of these models have attained less attention. Benigno (2004) analyzed optimal monetary policy in a two-country framework. Neglecting the role of fiscal policy, he showed that in the presence of idiosyncratic shocks to technology, stabilizing the price level is desirable from a welfare perspective. In a similar setting but including national fiscal authorities, Beetsma and Jensen (2005) furthermore found evidence that countercyclical spending on national level is welfare-enhancing from a union-wide perspective. As aformentioned, Galí and Monacelli (2008) also studied optimal monetary policy and the role of fiscal stabilization. In a multi-country framework they derived, however, quite similar implications how monetary and fiscal policy should be implemented. Based on the Galí and Monacelli (2008) model, Forlati (2008) analyzed fiscal policy under no-coordination. She found that the normative prescriptions emphasized by the authors abovementioned, are not valid any more once policymakers are not coordinated. In this case, optimal monetary policy does not imply that the central bank stabilize the average union inflation, because it has to take into account the distortions caused by the lack of coordination among fiscal policymakers. Ferrero $(2007,2009)$ additionally examined the role of distortionary taxation in a two-country framework, again from a union-wide perspective. In his setting, monetary policy should achieve aggregate price level stability, while fiscal policy should stabilize country-specific shocks via permanent variations of government spending and tax gaps but abstain from creating inflationary expectations at the union level.

A first step in introducing real rigidities in a two-country model of a currency union is done by Campolmi and Faia (2006). In contrast to this paper, however, they focussed on the investigation of the impact of labor market imperfections on inflation differentials between members, rather than on optimal policies. Closer to the framework used in this paper, is the modeling approach in Abritti (2007). However, he considered a world consisting of only two countries and additionally assumes market rigidities, which generate involuntary unemployment. In contrast to this paper, he introduced real wage rigidity that follows a stochastic process. Furthermore, both - Campolmi and Faia (2006) and Abritti (2007) - did not include a fiscal sector in their analysis. A welfare analysis or a derivation of optimal policies neither is part of their analyses.

Next to the literature on sticky price models of a currency union, papers using 
real wage rigidities in NK models should be briefly reviewed. Just recently Blanchard and Galí (2007) reconsidered the impact of rigid real wages on monetary policy design in a closed economy. Within a basic NK model, they showed that the presence of inertial adjustment of real wages leads to a notable trade-off in monetary policy design. They found that under this additional assumption, there is a trade-off between stabilizing inflation and the welfare relevant output. Moreover, they found that taking into account rigid real wages is a crucial element in understanding persistent inflation.

Next to sticky inflation dynamics, real wage rigidity can also help to explain observed labor market fluctuations. As shown by Hall (2005) and Shimer (2005) real wage rigidity is necessary to explain the large cyclical variation in job vacancies 1

Inspired by these papers, some richer sticky price models with rigid real wages - additionally considering labor market frictions - have been developed (e.g. Christoffel and Linzert, 2006 or Faia, 2008).

Especially in European countries, inertial real wage adjustment seems to be an important feature to properly understand labor market dynamics. It is often argued that European labor markets are rigid in many perspectives. High firing costs and unemployment benefits and in particular collective wage bargaining prevent wages from adjusting instantaneously. There is a lot of micro-founded theory for possible reasons intensifying this rigidity. Among others, one could mention efficient wage contracts, loss aversion, strong union power, or fairnes consideration $2^{2}$. Empirical evidence for rigid real wages has been given by a number of studies in recent year: ${ }^{3}$. They all attest relatively high real wage rigidity in the EU (compared to the US).

\section{The Model}

The model I use to derive the optimal monetary and fiscal policy in a currency union draws on the standard New Keynesian (NK) modeling approach as proposed in Galí (2008) and Galí and Monacelli (2005). This dynamic stochastic NK framework mainly differs from a standard Real Business Cycle (RBC) theory by the assumption of imperfect competition and nominal price rigidity. Galí and Monacelli (2008) extent the standard NK approach,

\footnotetext{
${ }^{1}$ However, the effects of real wage rigidity are still matter of some controversy. See for instance Mortensen and Nagypál (2007) for a critical review.

${ }^{2}$ For instance, Bewley (1999) provides an overview of recent research in this direction

${ }^{3}$ see e.g. , Bauer et al. (2004), Barwell and Schweitzer (2007), Deviciente et al. (2007), Dickens at al. (2007), Du Caju et al. (2007), Heckel et al. (2008), Holden and Wulfsberg (2007).
} 
which only considers one single economy, to a union of countries sharing the same currency. I expand the Galí and Monacelli model of a currency union by assuming real wage rigidities.

The world consists of a continuum of small open economies indexed by $i \in(0,1)$. Each economy is of measure zero, from this it follows that a domestic policy decision has no impact on the rest of the union. I assume that all countries share identical preferences, technologies, and market structures but different real wage rigidities.

\section{$3.1 \quad$ People}

Consider a typical country belonging to the union, say country $i$. The representative infinitely-lived household maximizes

$$
E_{0} \sum_{i=0}^{\infty} \beta^{t} U\left(C_{t}^{i}, N_{t}^{i}, G_{t}^{i}\right)
$$

where

$$
U\left(C_{t}^{i}, N_{t}^{i}, G_{t}^{i}\right) \equiv(1-\chi) \log C_{t}^{i}+\chi \log G_{t}^{i}-\frac{\left(N_{t}^{i}\right)^{1+\phi}}{1+\phi},
$$

with $\chi \in(0,1)$ as a weight attached to public consumption. That is, preferences are defined over the consumption of private and public goods, $C_{t}^{i}$ and $G_{t}^{i}$, and labor $N_{t}^{i}$, which is assumed to be immobile across countries 4 . The composite of private consumption is defined by:

$$
C_{t}^{i} \equiv \frac{\left(C_{i, t}^{i}\right)^{1-\alpha}\left(C_{F, t}^{i}\right)^{\alpha}}{(1-\alpha)^{(1-\alpha)} \alpha^{\alpha}}
$$

where $C_{i, t}^{i}$ represents the household's consumption of domestic goods. Formally spoken, $C_{i, t}^{i}$ is a CES aggregation of all goods produced in country $i$ itself, given by

$$
C_{i, t}^{i} \equiv\left(\int_{0}^{1} C_{i, t}^{i}(j)^{\frac{\epsilon-1}{\epsilon}} d j\right)^{\frac{\epsilon}{\epsilon-1}},
$$

where $j \in(0,1)$ denotes the type of good. As described below, I assume that each country produces a continuum of differentiated goods indexed by $j$, where each good is produced by a seperate firm. Moreover, there is no good produced in more than one country.

Nevertheless, people in country $i$ consume goods produced in foreign countries. That is, again a CES aggregation of the goods produced in all other member states indexed by

\footnotetext{
${ }^{4}$ One also could have introduced real money balances as an argument. However, if it enters additively (as empirical evidence suggests, see Ireland (2004) for the case of the U.S. and Andrés et al. (2006) for the case of EMU), money market equilibrium plays no role for the dynamics when the nominal interest rate is the monetary policy instrument. Therefore, money is ignored in the remainder.
} 
$f \in(0,1)$, namely:

$$
C_{F, t}^{i} \equiv \int_{0}^{1}\left(\int_{0}^{1} C_{f, t}^{i}(j)^{\frac{\epsilon-1}{\epsilon}} d j\right)^{\frac{\epsilon}{\epsilon-1}} d f
$$

The home bias in private consumption is denoted as $1-\alpha$. Alternatively, $\alpha$ can be understood as "index of openness" in country $i$. Finally, the elasticity of substitution between varieties produced within any country is represented by $\epsilon>1$.

As usual, maximization of (1) is subject to a sequence of flow budget constraints given by

$$
\int_{0}^{1} P_{t}^{i}(j) C_{i, t}^{i}(j) d j+\int_{0}^{1} \int_{0}^{1} P_{t}^{f}(j) C_{f, t}^{i}(j) d j d f+E_{t}\left\{Q_{t, t+1} B_{t+1}^{i}\right\} \leq B_{t}^{i}+W_{t}^{i} N_{t}^{i}-T_{t}^{i}
$$

for all $t=0,1,2, \ldots P_{t}^{f}(j)$ is the price of good $j$ produced in country $f$ in units of the common currency, $W_{t}^{i}$ denotes the nominal wage, $B_{t+1}^{i}$ represents the quantity of oneperiod, nominally riskless discount bonds purchased in period $t=0,1,2, \ldots$ and maturing in period $t+1$. Each bond pays one unit of the common currency and its price is $Q_{t}$, common across countries. $T_{t}^{i}$ is a lump-sum component of income, which may include, among other items, lump-sum taxes, dividends from ownership of (domestic) firms, etc.

In addition to (3), it is assumed that the representative household in each member country is subject to a solvency constraint that prevents it to rule out Ponzi-schemes:

$$
\lim _{T \rightarrow \infty} E_{t}\left\{B_{T}^{f}\right\} \geq 0
$$

for all $f \in(0,1)$.

The representative household in country $i$ seeks to optimally allocate a given level of expenditure across the various goods available. That is, it adjusts the share of a particular good in its consumption bundle to exploit any relative price differences, i.e. the cost of consumption is minimized. Optimizing expenditure for any individual good implies the demand functions of domestic and foreign goods, respectively:

$$
\begin{aligned}
C_{i, t}^{i}(j) & =\left(\frac{P_{t}^{i}(j)}{P_{t}^{i}}\right)^{-\epsilon} \\
C_{f, t}^{i}(j) & =\left(\frac{P_{t}^{f}(j)}{P_{t}^{f}}\right)^{-\epsilon},
\end{aligned}
$$

for all $i, f, j \in(0,1)$. Here, $P_{t}^{i} \equiv\left(\int_{0}^{1} P_{t}^{i}(j)^{1-\epsilon} d j\right)^{\frac{1}{1-\epsilon}}$ represents an index of prices of all domestically produced goods, for all $i \in(0,1)$. Since there are no trading frictions, the law of one price is assumed to hold in all single good markets. This implies, that one 
can equally define $P_{t}^{f} \equiv\left(\int_{0}^{1} P_{t}^{f}(j)^{1-\epsilon} d j\right)^{\frac{1}{1-\epsilon}}$ as a (producer) price index for the bundle of goods imported from country $f$. Reentering these definitions in (5) and (6) and rearranging terms yields

$$
\begin{aligned}
& \int_{0}^{1} P_{t}^{i}(j) C_{i, t}^{i}(j) d j=P_{t}^{i} C_{i, t}^{i} \\
& \int_{0}^{1} P_{t}^{f}(j) C_{f, t}^{i}(j) d j=P_{t}^{f} C_{f, t}^{i} .
\end{aligned}
$$

Moreover, the optimal allocation of expenditures implies:

$$
P_{t}^{f} C_{f, t}^{i}=P_{t}^{\star} C_{F, t}^{i}
$$

for all $f \in(0,1) . \quad P_{t}^{\star} \equiv \exp \int_{0}^{1} p_{t}^{f} d f$ denotes the union-wide price index. Note, that from the perspective of any individual country, $P_{t}^{\star}$ is also the price index of imported goods. By combining (8) and (9) one can write total expenditures on imported goods as $\int_{0}^{1} P_{t}^{f} C_{f, t}^{i} d f=P_{t}^{\star} C_{F, t}^{i}$.

Next, one can define the consumer price index $(\mathrm{CPI})$ as $P_{c, t}^{i} \equiv\left(P_{t}^{i}\right)^{1-\alpha}\left(P_{t}^{\star}\right)^{\alpha}$. From this it follows that one can write the optimal allocation of expenditures between domestic and imported goods, respectively, in country $i$ can be written as:

$$
\begin{aligned}
P_{t}^{i} C_{i, t}^{i} & =(1-\alpha) P_{c, t}^{i} C_{t}^{i} \\
P_{t}^{\star} C_{F, t}^{i} & =\alpha P_{c, t}^{i} C_{t}^{i} .
\end{aligned}
$$

Now, one can combine the previous results to write the total (optimal) consumption expenditures of the representative household in country $i$ as:

$$
P_{t}^{i} C_{i, t}^{i}+P_{t}^{\star} C_{F, t}^{i}=P_{c, t}^{i} C_{t}^{i}
$$

Finally, one can combine (3) and (12) to express the household's budget restriction as:

$$
P_{c, t}^{i} C_{i, t}^{i}+E_{t}\left\{Q_{t, t+1} D_{t+1}^{i}\right\} \leq D_{t}^{i}+W_{t}^{i} N_{t}^{i}+T_{t}^{i}
$$

Maximizing (1) with respect to $\left\{C_{t}^{i}\right\}_{t=0}^{\infty},\left\{G_{t}^{i}\right\}_{t=0}^{\infty}$, and $\left\{N_{t}^{i}\right\}_{t=0}^{\infty}$ and subject to 13) and (4), leads to the optimality conditions:

$$
\begin{aligned}
& \frac{C_{t}^{i}\left(N_{t}^{i}\right)^{\phi}}{1-\chi}=\frac{W_{t}^{i}}{P_{c, t}^{i}} \\
& \beta R_{t}^{\star} E_{t}\left\{\left(\frac{C_{t}^{i}}{C_{t+1}^{i}}\right)\left(\frac{P_{c, t}^{i}}{P_{c, t+1}^{i}}\right)\right\}=1,
\end{aligned}
$$


where $R_{t}^{\star}=\frac{1}{E_{t}\left\{Q_{t, t+1}\right\}}$ denotes the usual gross nominal one-period return. Alternatively, one can write the marginal rate of substitution (MRS) between consumption and leisure in (14) and the Euler equation in (15) in log-linearized form (henceforth lower case letters denote the logs of the respective variables):

$$
\begin{aligned}
& w_{t}^{i}-p_{c, t}=c_{t}^{i}+\phi n_{t}^{i}-\log (1-\chi) \\
& c_{t}^{i}=E\left\{c_{t+1}^{i}\right\}-\left(r_{t}^{\star}-E_{t}\left\{\pi_{c, t+1}^{i}\right\}-\rho\right),
\end{aligned}
$$

where the CPI inflation is defined as $\pi_{c, t}^{i} \equiv p_{c, t}^{i}-p_{c, t-1}^{i}$ and $\rho \equiv-\log \beta$ denotes the time discount rate.

\subsubsection{Some Definitions and Identities}

Before proceeding with the analyses, I introduce some definitions and identities that I will need in the following. First, I determine the effective terms of trade between two countries, say country $i$ and $f$. That is, the price of country $f$ 's domestically produced goods in terms of country $i$ 's. Thus, formally spoken I define the effective terms of trade as:

$$
\mathcal{S}_{f, t}^{i} \equiv \frac{P_{t}^{f}}{P_{t}^{i}}
$$

Consequently, I define the effective terms of trade for country $i$ as:

$$
\begin{aligned}
\mathcal{S}_{t}^{i} & \equiv \frac{\int_{0}^{1} P_{t}^{i} d i}{P_{t}^{i}}=\frac{P_{t}^{\star}}{P_{t}^{i}} \\
& =\exp \int_{0}^{1}\left(p_{t}^{f}-p_{t}^{i}\right) d f \\
& =\exp \int_{0}^{1} s_{f, t}^{i}
\end{aligned}
$$

Alternatively, writing 16 in logs yields $s_{t}^{i}=\int_{0}^{1} s_{f, t} d f$. Using the definition of CPI and (16), one can relate $P_{c, t}^{i}$ and domestic price level $P_{t}^{i}$ according to:

$$
P_{c, t}^{i}=P_{t}^{i}\left(\mathcal{S}_{t}^{i}\right)^{\alpha}
$$

or in logs

$$
p_{c, t}^{i}=p_{t}^{i}+\alpha s_{t}^{i}
$$

Substracting a lagged version of (17) from the same equation one can also relate domestic inflation, i.e. $\pi_{t}^{i} \equiv p_{t}^{i}-p_{t-1}^{i}$, and CPI inflation according to:

$$
\pi_{c, t}^{i}=\pi_{t}^{i}+\alpha \Delta s_{t}^{i}
$$


This makes clear that the gap between CPI inflation and domestic inflation is equal to the percentage (since expressed in logs) change in terms of trade proportionally to the index of openness. Obviously, considering the aggregate price level, one has $p_{c, t}^{\star}=p_{t}^{\star}$ and hence $\pi_{c, t}^{\star}=\pi_{t}^{\star}$, since terms of trade vanish of course for the union as a whole. Formally, this can be seen by intergrating 17 over $i$ and using the fact that $\int_{0}^{1} s_{t}^{i} d i=0$.

\subsubsection{International Risk Sharing}

I assume that financial markets are complete both at the domestic and at the international level. Furthermore, each individual's initial holding of any type of asset is zero. These assumptions imply perfect consumption risksharing within each country and equalization of the marginal utilities of consumption between countries:

$$
\beta R_{t}^{\star} E_{t}\left\{\left(\frac{C_{t}^{i}}{C_{t+1}^{i}}\right)\left(\frac{P_{c, t}^{i}}{P_{c, t+1}^{i}}\right)\right\}=\beta R_{t}^{\star} E_{t}\left\{\left(\frac{C_{t}^{f}}{C_{t+1}^{f}}\right)\left(\frac{P_{c, t}^{f}}{P_{c, t+1}^{f}}\right)\right\},
$$

for all $i, f \in(0,1)$. This implies:

$$
\frac{C_{t}^{f}}{C_{t}^{i}}=\frac{P_{c, t}^{f}}{P_{c, t}^{i}}
$$

Therefore, under complete markets, the MRS between home and other country consumption has to equal the corresponding relative price. Combining $(18)$ and the definitions of the terms of trade yields:

$$
C_{t}^{i}=v_{i} C_{t}^{f}\left(\mathcal{S}_{f, t}^{i}\right)^{1-\alpha}
$$

for all $i, f \in(0,1)$ and where $v_{i}$ is a constant generally depending on initial conditions. As aforementioned, and without loss of generality, I assume symmetric initial conditions (i.e., zero net foreign asset holdings and an ex-ante identical environment), in which case one has $v_{i}=v=1$ for all $i \in(0,1)$. Taking logs of $(19)$ yields:

$$
c_{t}^{i}=c_{t}^{\star}+(1-\alpha) s_{t}^{i},
$$

where $c_{t}^{\star} \equiv \int_{0}^{1} c_{t}^{f} d f$.

\subsubsection{Introducing Real Wage Rigidities}

In Europe (and to a some degree in the US) there are no sudden and significant shifts in the aggregate wage level observed. Moreover, due to collective wage-bargaining agreements, wages change only infrequently. Hence, a wage that can be freely adjusted in each period 
is hardly consistent with (European) reality. For this reason, many authors have recently focused on the examination of sluggish wage adjustment.

Erceg, Henderson, and Levin (2000) and Christiano, Eichenbaum, and Evans (2005) introduced nominal wage rigidity into the New Keynesian business cycle model by a Calvo type wage setting scheme. As in final good price setting, firms are randomly chosen to change their wages while the remaining firms keep wages unchanged. However, in Europe, most wages are bargained on a sector wide level, and are not allowed to fluctuate freely: once settled they remain unchanged for a given period. Moreover, as argued in Christoffel and Linzert (2005) the Calvo wage rigidity modeling strategy neglects the crucial interdependence of the wage bargaining process with other labor market issues, like the flows in and out of employment or the level of unemployment. Furthermore, Hall (2005) and Shimer (2005) have argued that real (and not nominal) wage rigidity is central to explaining the cyclical behavior of unemployment and vacancies.

Hall (2005) proposed a modeling strategy of sluggish wage adjustment that improves the cyclical properties of labor market models. He introduced wage rigidity as a constant wage rule, which may be interpreted as a wage norm or social consensus. In this paper I use a version of Hall's notion of a wage norm in order to introduce real wage rigidity. In particular, I assume that the real wage $W_{r, t}^{i}$ paid to a worker in country $i$ in period $t=0,1,2, \ldots$ is a weighted average of a notional real wage $W_{n, t}^{i}$ and a wage norm $\bar{W}$, i.e.

$$
W_{r, t}^{i}=\left(W_{n, t}^{i}\right)^{\kappa^{i}}\left(\bar{W}^{i}\right)^{1-\kappa^{i}}
$$

with $0 \leq \kappa^{i} \leq 1$. Of course, this form of real wage adjustment is unmodeled and ad hoc 5 , but it can be thought of as a reduced-form representation of a more intricate search unemployment setup. A micro foundation of such a setup has been discussed in Bodart et al. (2006). Concretely, I set $W_{n, t}^{i}=W_{r, t-1}^{i}$ and $\bar{W}^{i}=M R S_{t}$. Thus, I assume a partial adjustment model of the form:

$$
\frac{W_{t}^{i}}{P_{c, t}^{i}}=\left(\frac{W_{t-1}^{i}}{P_{c, t-1}^{i}}\right)^{\kappa^{i}}\left(M R S_{t}^{i}\right)^{1-\kappa^{i}},
$$

or written in logs

$$
w_{t}^{i}-p_{c, t}^{i}=\kappa^{i}\left(w_{t-1}^{i}-p_{c, t-1}^{i}\right)+\left(1-\kappa^{i}\right) m r s_{t}^{i},
$$

\footnotetext{
${ }^{5}$ As shown in Blanchard and Galí (2007) a more complex model with staggered real wage setting would lead to similar conclusions.
} 
where $\kappa \in[0,1]$ for all $i \in(0,1)$ indicates the degree of real persistence in country 6 . This approach is used in several recent papers, e.g. Blanchard and Galí (2007), Christoffel and Linzert (2005), Faia (2008), Campolmi and Faia (2006), Krause and Lubik (2007) and Uhlig (2007). Although I do not provide a micro foundation of this approach within my model, it constitutes a plausible starting point for analyzing the impact of real wage rigidities on the dynamics of the economy and, hence, on monetary and fiscal policy.

\subsection{Policy Authorities}

The monetary policy instrument of the common monetary authority is the union-wide nominal interest rate $R_{t}^{\star}$. (A discussion on how monetary policy should be conducted is let to section 6.3.) Following Woodford (2003), the model abstracts from monetary frictions and considers the limit of a "cashless economy". Hence, seigniorage does not represent a source of revenues for national governments.

In contrast to the nominal interest rate, fiscal policy is not common across all member countries. Similarly to private consumption of domestic and imported goods, I define country $i$ 's household's public consumption $G_{t}^{i}$. That is, $G_{t}^{i}$ is again a CES aggregation of all public consumption goods available:

$$
G_{t}^{i} \equiv\left(\int_{0}^{1} G_{t}^{i}(j)^{\frac{\epsilon-1}{\epsilon}} d j\right)^{\frac{\epsilon}{\epsilon-1}}
$$

where $G_{t}^{i}(j)$ denotes the consumption of good $j \in(0,1)$ or equivalently the quantity of good $j$ purchased by the government. Hence, I assume that the national governments only purchase goods produced in their own country 7 . While this is an extreme situation, fiscal policy remains effective at stabilizing the individual economies in the face of asymmetric disturbances as long as the public spending indices remain biased towards nationally produced goods. As will become evident below, government spending will be expansionary when prices and/or real wages are sticky. As in the case of private consumption one can derive the government demand schedules for each public good available. Here, I assume that the government allocates expenditures across individual goods, to minimize total cost.

\footnotetext{
${ }^{6}$ Generally, one would want to guarantee that the real wage exceeds the MRS at all times, to prevent workers from working more than desired, given the wage. For this reason, I consider the real wage in country $i$ from the household's perspective, i.e. $\frac{W_{t}}{P_{c, t}^{i}}$ and not the real wage in terms of the producer price index given by $\frac{W_{t}^{i}}{P_{t}^{i}}$

${ }^{7}$ For instance, Brulhart and Trionfetti (2004) found evidence for (strong) home bias.
} 
That is, the demand for good $j$ for all $j \in(0,1)$ is given by:

$$
G_{t}^{i}(j)=\left(\frac{P_{t}^{i}(j)}{P_{t}^{i}}\right)^{-\epsilon} G_{t}^{i}
$$

To simplify matters, I assume that public spending is financed either by debt issuance or lump-sum taxation, so that Ricardian equivalence holds. If one was to abolish the assumption that the government can levy lump-sum taxes, changes in the amount of public spending would lead to fluctuations in distortionary taxes, thereby affecting the supply-side of the economy and potentially diminishing the stimulating effect of an increase in government spending. Technically, this would cause static steady state distortions 8 , However, analyzing the effect of distortionary taxation, is beyond the scope of this paper ${ }^{9}$.

\subsection{Firms}

In any individual country, a continuum of firms produces a single good each, indexed by $j \in(0,1)$. They sell their products in monopolistic competitive goods markets. To guarantee a pareto efficient steady state of the economy, I assume a constant subsidy to labor $\tau^{i}$, financed by lump-sum taxes, to undo the distortions caused by imperfect competition ${ }^{19 \mid 1}$. Goods are produced making use of labor. Thus, the production function for each good $j \in(0,1)$ produced in each country $i \in(0,1)$ has the linear form:

$$
Y_{t}^{i}(j)=A_{t}^{i} N_{t}^{i}(j)
$$

or in logs:

$$
y_{t}^{i}(j)=a_{t}^{i}+n_{t}^{i}(j)
$$

where $a_{t}^{i}$ is a coutry specific exogenous stochastic technological factor common to all firms in the respective country. This productivity shifter is assumed to follow an AR(1) process, given by:

$$
a_{t}^{i}=\rho_{a} a_{t-1}^{i}+\epsilon_{t}^{i}, \quad \epsilon \sim W N\left(0, \sigma_{\epsilon}\right),
$$

\footnotetext{
${ }^{8}$ This requires employing the methodology of Benigno and Woodford (2006) to derive an approximated union-wide welfare objective.

${ }^{9}$ Ferrero $(2007,2009)$ analyzes the effect of distortionary taxation in a two-country model of a currency union.

${ }^{10}$ In the appendix (available upon request) I show, how this subsidy should be set, so that the steady state of the economy involves an effcient level of output.

${ }^{11}$ This approach is extensively used in recent literature. For instance, see Rotemberg and Woodford (1997), Benigno and Benigno (2000), and Woodford (2002) for a discussion in the framework of a microfounded model with staggered price-setting and imperfect competition.
} 
with $\rho_{a} \in(0,1)$. Due to the labor subsidy, the firms' profits per unit of productivity are $P_{t}^{i}(j) Y_{t}^{i}(j)-\left(1-\tau^{i}\right) \frac{W_{t}^{i} i}{P_{t}^{i}} N_{t}^{i}(j) / A_{t}^{i}$ for all $j \in(0,1)$. The linear technology implies that the real marginal costs are independent of the level of production and, hence, are common across firms. Marginal costs in logs are given by:

$$
m c_{t}^{i}=\log \left(1-\tau^{i}\right)+\left(w_{t}^{i}-p_{t}^{i}\right)-a_{t}^{i}
$$

12

Similar to aggregate consumption, I define the aggregate output of $i$ 's economy as

$$
Y_{t}^{i} \equiv\left(\int_{0}^{1} Y_{t}^{i}(j)^{\frac{\epsilon-1}{\epsilon}} d j\right)^{\frac{\epsilon}{\epsilon-1}}
$$

Next, I define

$$
Z_{t}^{i} \equiv \int_{0}^{1} \frac{Y_{t}^{i}(j)}{Y_{t}^{i}} d j
$$

Combining (23), (24), and the technology in (21), one can write the amount of labor hired as

$$
N_{t}^{i}=\int_{0}^{1} N_{t}^{i}(j) d j=\frac{Y_{t}^{i} Z_{t}^{i}}{A_{t}^{i}}
$$

It will be seen below that in equilibrium, i.e. when the economy's resource constraint holds, $Z_{t}^{i}=\int_{0}^{1}\left(\frac{P_{t}^{i}(j)}{P_{t}^{i}}\right)^{-\epsilon} d j$. Thus, $Z_{t}^{i}$ can be interpreted as an index of the relative price dispersion across firms.

Note, that given the definitions in (23) and (25), one can state the aggregate relation between output and employment in logs as:

$$
y_{t}^{i}=a_{t}^{i}+n_{t}^{i}
$$

A basic assumption of the NK approach are nominal rigidities. Firms are subject to some constraints on the frequency with which they can adjust their prices of the goods they sell. A current modeling strategy is to use the formalism proposed in Calvo (1983). That is, each firm may reset its price only with probability $1-\theta$ in any given period, independent of the time elapsed since the last adjustment. Hence, in each period only a fraction of $1-\theta$ of all producers reset their prices, while the rest, $\theta$, keep their prices unchanged. As a consequence, the average duration of a price is given by $(1-\theta)^{-1}$ and $\theta$

\footnotetext{
${ }^{12}$ Notice that $w_{t}^{i}-p_{t}^{i}$ denotes the real wage in terms of the $(\log )$ producer price index $p_{t}^{i}$. As abovementioned, I differenciate between producer and consumer price indeces, i.e. the (log) real wage from the consumer's perspective is given by $w_{t}^{i}-p_{c, t}^{i}$.
} 
can be naturally interpreted as an index of price stickiness. It can be shown that if prices are set à la Calvo, maximizing profits yields the optimal price setting strategy:

$$
\bar{p}_{t}^{i}=\mu+(1-\beta \theta) \sum_{k=0}^{\infty}(\beta \theta)^{k} E_{t}\left\{m c_{t+k}^{i}+p_{t+k}^{i}\right\},
$$

where $\bar{p}_{t}^{i}$ denotes the log of newly set prices in country $i$ and $\mu \equiv \log \frac{\epsilon}{\epsilon-1}$ is the $\log$ of the desired gross mark-up prevailing in a zero inflation steady state ${ }^{13}$. Hence, firms resetting their prices will choose a price that corresponds to the desired mark-up over a weighted average of their current and expected (nominal) marginal costs, with the weight being proportional to the probability of the price remaining effective at each horizon $\theta^{k}$.

\subsection{The Dynamic Equilibrium}

In this section I summarize conditions determining the dynamic equilibrium of the system. The following definition characterizes an equilibrium:

DEFINITION 3.1. Given fiscal and monetary policies and exogenous processes, an imperfectly competitive equilibrium is a sequence of quantities and prices such that:

1. Households in each country maximize utility subject to their flow budget constraint and a natural borrowing limit, taking prices as given.

2. Firms in each country maximize profits subject to their technology constraint, taking as given the demand for their goods.

3. All markets clear.

\subsubsection{Demand and Output Determination - The Dynamic IS Equation}

In the following I derive an equation characterizing part one of the above definition of a dynamic equilibrium, namely the demand side of the economy in country $i$. By definition, being in equilibrium implies that markets are cleared. Thus, clearing the market for good $j$ consumed in $i$ requires:

$$
Y_{t}^{i}(j)=C_{i, t}^{i}(j)+\int_{0}^{1} C_{i, t}^{f}(j) d f+G_{t}^{i}(j) .
$$

\footnotetext{
${ }^{13} \mathrm{~A}$ more detailed discussion of the price setting scheme as well as the role of the mark-up is delivered in an appendix which is available upon request.
} 
Using the optimal allocation of expenditures between domestic and imported goods determined by (5), (6), (10), and (11) one can write the latter equation as:

$$
Y_{t}^{i}(j)=\left(\frac{P_{t}^{i}(j)}{P_{t}^{i}}\right)^{-\epsilon}\left[(1-\alpha)\left(\frac{P_{c, t}^{i}}{P_{t}^{i}}\right) C_{t}^{i}+\alpha \int_{0}^{1}\left(\frac{P_{c, f}^{f}}{P_{t}^{i}}\right) C_{t}^{f} d f+G_{t}^{i}\right] .
$$

Alternatively, this expression can be combined with the definitions of the terms of trade in section 3.1.1. to get:

$$
Y_{t}^{i}(j)=\left(\frac{P_{t}^{i}(j)}{P_{t}^{i}}\right)^{-\epsilon}\left[(1-\alpha)\left(\mathcal{S}_{t}^{i}\right)^{\alpha} C_{t}^{i}+\alpha\left(\mathcal{S}_{t}^{i}\right)^{\alpha} \int_{0}^{1}\left(\mathcal{S}_{f, t}^{i}\right)^{1-\alpha} C_{t}^{f} d f+G_{t}^{i}\right]
$$

Finally, making use of (19), one can write the market clearing condition for good $j$ in country $i$ as:

$$
Y_{t}^{i}(j)=\left(\frac{P_{t}^{i}(j)}{P_{t}^{i}}\right)^{-\epsilon}\left[C_{t}^{i}\left(\mathcal{S}_{t}^{i}\right)^{\alpha}+G_{t}^{i}\right]
$$

In order to derive an expression for aggregate demand, I combine the latter equation with the aggregate output in country $i$ defined by (23). This yields:

$$
Y_{t}^{i}=C_{t}^{i}\left(\mathcal{S}_{t}^{i}\right)^{\alpha}+G_{t}^{i}
$$

where the term $C_{t}^{i}\left(\mathcal{S}_{t}^{i}\right)^{\alpha}$ describes the total private consumption in country $i$. For further references, it will be useful to express key equations of the economy's equilibrium in terms of $(\log )$ deviations from a steady state. Thus, the aggregated goods market clearing condition in (29) approximated around a symmetric zero inflation steady state gives (Henceforth, a hat denotes the deviation from a steady state of the respective variable.):

$$
\hat{y}_{t}^{i}=(1-\gamma)\left(\hat{c}_{t}^{i}+\alpha s_{t}^{i}\right)+\gamma \hat{g}_{t}^{i},
$$

where $\gamma \equiv \frac{G}{Y}$ is the efficient steady state government spending share ${ }^{14}$, and therefore $(1-\gamma)$ denotes the steady state share of private consumption ${ }^{15}$. Note, that $\hat{s}_{t}^{i}=s_{t}^{i}$, since $\bar{s}=0$. (In the following a bar denotes the steady state value of the respective variable.)

The expression in 30 provides first evidence describing the dynamics in the domestic goods market. Not surprisingly, aggregate output is positively related to domestic consumption and government spending. Moreover, it is also connected positively to the effective terms of trade, depending proportionally on the "index of openness". This fact can be explained by foreign demand. To see this more clearly, one can derive an expression

\footnotetext{
${ }^{14}$ See appendix for a detailed discussion of the efficient steady state of this model.

${ }^{15} \mathrm{~A}$ detailed discussion and a proper derivation of an efficient zero-inflation steady state allocation is let to the appendix.
} 
for (30) in terms of foreign, i.e. union-wide, demand. By combining the latter equation with 16 and $(19)$, one can describe the dynamics in the domestic goods market as:

$$
\hat{y}_{t}^{i}=\gamma \hat{g}_{t}^{i}+(1-\gamma) \hat{c}_{t}^{\star}-(1-\gamma)\left(p_{t}^{i}-p_{t}^{\star}\right)
$$

Equation (31) establishes that country $i$ 's output is, next to domestic government spending, positively related to union-wide consumption (which is an index for the strength of foreign demand), and inversely related to domestic prices (relative to average prices in the union). By integrating (31) over $i$, one obtains the union wide market clearing condition:

$$
\hat{y}_{t}^{\star}=\gamma \hat{g}_{t}^{\star}+(1-\gamma) \hat{c}_{t}^{\star}
$$

Now, using previous results, one can derive one of the key equations in NK models: the dynamic IS equation (or DIS, for short).

First, I consider the home economy in country $i$. Notice that the Euler equation in (15) can be written in terms of log deviations from the steady state as:

$$
\hat{c}_{t}^{i}=E_{t}\left\{\hat{c}_{t+1}^{i}\right\}-\left(r_{t}^{\star}-E_{t}\left\{\pi_{c, t+1}^{i}\right\}-\rho\right) .
$$

Combining this expression with (30) yields the domestic DIS equation (approximated around a symmetric steady state):

$$
\hat{y}_{t}^{i}=E_{t}\left\{\hat{y}_{t+1}^{i}\right\}-(1-\gamma)\left(r_{t}^{\star}-E_{t}\left\{\pi_{c, t+1}^{i}\right\}-\rho\right)-(1-\gamma) \alpha E_{t}\left\{\Delta s_{t+1}^{i}\right\}-\gamma E_{t}\left\{\Delta \hat{g}_{t+1}^{i}\right\} .
$$

This equation fully characterizes the demand side of country $i$ 's economy. Obviously, this equilibrium condition has to hold for all member countries indexed by $i \in(0,1)$. Consequently, one can derive the union-wide DIS equation by intergrating (33) over $i$ :

$$
\hat{y}_{t}^{\star}=E_{t}\left\{\hat{y}_{t+1}^{\star}\right\}-(1-\gamma)\left(r_{t}^{\star}-E_{t}\left\{\pi_{t+1}^{\star}\right\}-\rho\right)-\gamma E_{t}\left\{\Delta \hat{g}_{t+1}^{\star}\right\}
$$

\subsubsection{Aggregate Supply - The New Keynesian Phillips Curve}

The next task is to derive the second key equation that summarizes the dynamics on the supply side of the economy. It can be shown that the profit maximizing price-setting strategy (27) can be manipulated such that one finally gets an expression that determines the inflation dynamics in the economy. This equation is often referred to as New Keynesian Phillips Curve (or NKPC, for short) and is given by:

$$
\pi_{t}^{i}=\beta E_{t}\left\{\pi_{t+t}^{i}\right\}+\lambda \widehat{m c} c_{t}^{i}
$$


where $\lambda \equiv(1-\beta \theta)(1-\theta) \theta^{-1}$ is strictly increasing in the index of price stickiness. $\widehat{m c}_{t}^{i}$ denotes the log deviation of marginal cost from its steady state value $\bar{m} c=-\mu^{16}$, Solving (35) under rational expectations yields:

$$
\pi_{t}=\lambda \sum_{k=0}^{\infty} \beta^{k} E_{t}\left\{\widehat{m c}_{t+k}^{i}\right\} .
$$

Additionally, by defining the average mark-up in the economy as $\mu_{t}=m c_{t}$, it is seen that inflation will be high when firms expect average mark-ups, and hence marginal costs, to be below their steady state level $\mu$. In that case, firms that have the opportunity to reset their prices will choose a price above the economy's average price level in order to arrange their mark-up closer to its steady state level.

Hence, inflation results from aggregate firms' price-setting decisions, which in turn are determined by current and expected real marginal costs. Accordingly, it makes sense to analyze the cyclical behavior of marginal costs. For this purpose, I derive a relation between economy's real marginal costs and key variables measuring aggregate economic activity.

Note first that one can write marginal costs in $(22)$ as:

$$
m c_{t}^{i}=\left(w_{t}^{i}-p_{c, t}^{i}\right)+\left(p_{c, t}^{i}-p_{t}^{i}\right)-a_{t}^{i}+\log \left(1-\tau^{i}\right) .
$$

This can be combined with (17) to get:

$$
m c_{t}^{i}=\left(w_{t}^{i}-p_{c, t}^{i}\right)+\alpha s_{t}^{i}-a_{t}^{i}+\log \left(1-\tau^{i}\right)
$$

From (36) it can be seen that an increase in productivity must lead either to an increase in real wages or terms of trade, or a decrease in (real) marginal costs. As it will be evident later, depending on how policy is conducted, the outcome is either reflected in output or inflation.

Combining this expression of marginal costs with the partial adjustment real wage equation in 20 one gets :

$$
\begin{aligned}
m c_{t}^{i}= & \kappa^{i} m c_{t-1}^{i}+\left(1-\kappa^{i} L\right)\left(\alpha s_{t}^{i}-a_{t}^{i}+\log \left(1-\tau^{i}\right)\right) \\
& +\left(1-\kappa^{i}\right)\left(c_{t}^{i}+\phi n_{t}^{i}-\log (1-\chi)\right) \\
= & \alpha s_{t}^{i}-a_{t}^{i}+\log \left(1-\tau^{i}\right)+\frac{1-\kappa^{i}}{1-\kappa^{i} L}\left(c_{t}^{i}+\phi n_{t}^{i}-\log (1-\chi)\right) .
\end{aligned}
$$

\footnotetext{
${ }^{16}$ It is evident from basic micro theory (e.g. Wolfstetter, 2002) that the desired mark-up under flexible prices and wages is $m c_{t}=\bar{m} c=\mu$ for all $t=0,1,2, \ldots$
} 
Expression (37) suggests that the higher the real wage rigidity, the higher the inertial adjustment of real marginal costs. This is in line with empirical evidence. In a seminal paper Galí, Gertler and Lopez- Salido $(2001,2003)$ found empirically that real wage rigidity is indeed a significant factor in accounting for sluggish cyclical movement in marginal costs.

In order to express the latter equations in terms of deviations from the steady state I make use of (26), (30) and the fact that $\bar{s}^{i}=0$ and $\bar{a}^{i}=1$.

$$
\begin{aligned}
\widehat{m c}_{t}^{i}= & \kappa^{i} \widehat{m c}_{t-1}^{i}+\left(1-\kappa^{i} L\right)\left(\alpha s_{t}^{i}-a_{t}^{i}\right) \\
& +\left(1-\kappa^{i}\right)\left(\left(\phi+\frac{1}{1-\gamma}\right) \hat{y}_{t}^{i}-\frac{\gamma}{1-\gamma} \hat{g}_{t}^{i}-\alpha s_{t}^{i}-\phi a_{t}^{i}\right) \\
= & \alpha s_{t}^{i}-a_{t}^{i}+\frac{1-\kappa^{i}}{1-\kappa^{i} L}\left(\left(\phi+\frac{1}{1-\gamma}\right) \hat{y}_{t}^{i}-\frac{\gamma}{1-\gamma} \hat{g}_{t}^{i}-\alpha s_{t}^{i}-\phi a_{t}^{i}\right)
\end{aligned}
$$

It is seen that marginal costs depend positively (negatively) on current (lagged) terms of trade (proportionally depending on $\alpha$ ). This can be explained by rigid real wages from the households' perspective, i.e. assessed in terms of current and lagged CPI (which in turn depends on the terms of trade as shown above). Interestingly, there is a negative relationship between public spending and marginal costs (depending on the index of real wage rigidity). The rationale for this is simple: given the output, an increase in government spending crowds out domestic consumption and/or generates a real appreciation, both of which tend to reduce real marginal costs through their negative effect on the product wage. In addition, the negative effect of government spending on marginal costs increases in $\gamma$. To make this clear, consider the following situation: Given an increase in output while government spending and technology remain unchanged, a larger $\gamma$ would increase consumption and/or terms of trade; both would lead to a higher product price and, thus, marginal costs would decline.

Since marginal costs feed into the determination of prices through the NKPC, I establish a direct channel of real wage rigidities to translate into aggregate inflation of country $i$. This is done by combining 35 and 40 . Multiplying the resulting expression by $\frac{1-\kappa^{i} L}{1-\kappa^{i}}$ and rearranging terms finally yields:

$$
\begin{aligned}
\pi_{t}^{i}= & \kappa^{i} \pi_{t-1}^{i}+\beta E_{t}\left\{\pi_{t+1}^{i}\right\}-\kappa^{i} \beta E_{t-1}\left\{\pi_{t}\right\}+\lambda \kappa^{i} \alpha \Delta s_{t}^{i}-\lambda\left(1+\left(1-\kappa^{i}\right) \phi\right) a_{t}^{i} \\
& +\lambda \kappa^{i} a_{t-1}^{i}+\lambda\left(1-\kappa^{i}\right)\left(\phi+\frac{1}{1-\gamma}\right) \hat{y}_{t}^{i}-\frac{\lambda\left(1-\kappa^{i}\right) \gamma}{1-\gamma} \hat{g}_{t}^{i} .
\end{aligned}
$$

Integrating this expression over all member states, yields the NKPC for the union as a 
whole, namely

$$
\begin{aligned}
\pi_{t}^{\star}= & \kappa^{\star} \pi_{t-1}^{\star}+\beta E_{t}\left\{\pi_{t+1}^{\star}\right\}-\kappa^{\star} \beta E_{t-1}\left\{\pi_{t}\right\}-\lambda\left(1+\left(1-\kappa^{\star}\right) \phi\right) a_{t}^{\star} \\
& +\lambda \kappa^{\star} a_{t-1}^{\star}+\lambda\left(1-\kappa^{\star}\right)\left(\phi+\frac{1}{1-\gamma}\right) \hat{y}_{t}^{\star}-\frac{\lambda\left(1-\kappa^{\star}\right) \gamma}{1-\gamma} \hat{g}_{t}^{\star} .
\end{aligned}
$$

where $\kappa^{\star} \equiv \int_{0}^{1} \kappa^{i} d i$ and $a_{t}^{\star} \equiv \int_{0}^{1} a_{t}^{i} d i$ for all $i \in(0,1)$.

So far, I have derived a log-linear equilibrium according to the definition above. Given a function for government spending and a nominal interest rate characterizing the monetary

policy, that equilibrium can be summarized for each individual economy by (33) and (41), or for the union as a whole by (34) and (42).

\section{Calibration and Implementation}

In the following numerical analysis of the model, I assume that time is taken as quarters. I set the discount factor $\beta=0.99$, so that the riskless annual return is about 4 percent. Following Galí and Monacelli (2008) I set the value added steady state mark-up of prices over marginal costs to 1.2. This generates a value for the price elasticity of demand, $\epsilon$, of 6 . Moreover, I assume a labor supply elasticity of $1 / 3$, which implies that $\phi=3$. That roughly goes in line with empirical findings for the Euro Area (e.g. Smets and Wouters, 2003). The degree of domestic and union-wide real wage rigidity is set to a benchmark value of 0.8 . This value implies a half-live of deviations of the real wage from its equilibrium level of about 3 quarters, what corresponds to recent empirical evidence for the euro area in Arpaia and Pichelmann (2007). The Calvo parameter is set to 0.8, which corresponds to an average nominal price duration of five quarters, which is in line with the empirical findings for the euro area in Altissimo, Ehrmann and Smets (2006). For the degree of home bias in private consumption, I follow Forlati (2007) and set $\alpha=0.4$. The weight of the public bundle in the preferences is set to $\chi=\gamma=0.25$, which roughly corresponds to the average share of government consumption in GDP for the EMU. Finally, by following standard RBC literature (e.g. Backus et al., 1992), I calibrate the domestic productivity shock as a first order autoregressive process with standard deviations to 0.008 and persistence to 0.95 . I assume the union-wide (symmetric) shock to technology to have the same stochastic properties. If not indicated differently, I further assume this baseline calibration in the following quantitative analysis.

In order to solve the system of linear rational-expectations equations with lagged expectations, I follow the numerical procedure proposed by Meyer-Gohde (2007)but with 
some computational extensions. Basically, this approach is based on the method of undetermined coefficients for the infinite MA representation. A detailed discussion of the implementation procedure as well as the underlying source codes is let to a technical appendix which is available upon request.

\section{Results}

\subsection{Policy Trade-offs}

\subsubsection{Member Country's Trade-off}

In a foregoing section, I have derived a dynamic equilibrium in terms of real (aggregate) variables. In order to better interpret the business cycle behavior of the economy from a welfare point of view, I further use the conventional notation of gap variables. That is, from now on I consider the deviations of the actual economy's variables from the welfare optimal level (i.e. the outcome in a pareto efficient allocation). That is, the smaller the gaps are, the smaller the welfare losses.

To rewrite the equilibrium equations derived above, in terms of gap variables, notice first that marginal costs in an economy with no distortions and flexible prices and wages are given by:

$$
\overline{m c}_{t}^{i}=\bar{c}_{t}^{i}+\phi \bar{n}_{t}^{i}+\alpha \bar{s}_{t}^{i}-a_{t}^{i}-\log (1-\chi) .
$$

for all $i \in(0,1)$ and $t=0,1,2, \ldots$

Perfect competition implies that there is no price mark-up set by the firms and real marginal costs are constant, given by $\overline{m c}_{t}^{i}=-\mu$. Thus, one has: $\widehat{\overline{m c}}_{t}^{i}=\overline{m c}_{t}^{i}+\mu=0$. Using the same results as for computing (40, , one can write the deviations of marginal costs from their steady state value as:

$$
\widehat{\overline{m c}}_{t}^{i}=\left(\frac{1}{1-\gamma}+\phi\right) \hat{\bar{y}}_{t}^{i}-\frac{\gamma}{1-\gamma} \hat{\bar{g}}_{t}^{i}-(1+\phi) a_{t}^{i}=0
$$

for all $i \in(0,1)$ and $t=0,1,2, \ldots$

Next, I define $\tilde{y}_{t}^{i} \equiv y_{t}^{i}-\bar{y}_{t}^{i}$ and $\tilde{g}_{t}^{i} \equiv g_{t}^{i}-\bar{g}_{t}^{i}$ as output gap and government spending gap. Moreover, I define a measure for the fiscal stance: $\tilde{f}_{t}^{i} \equiv \tilde{g}_{t}^{i}-\tilde{y}_{t}^{i}=\left(g_{t}^{i}-y_{t}^{i}\right)-\log \chi$ which I henceforth refer to as the fiscal gap. Using these definitions and imposing an optimal steady state government spending share $(\gamma=\chi)$, one can substract (43) from 
(41) to rewrite the NKPC for country $i$ in terms of gap variables

$$
\begin{aligned}
\pi_{t}^{i}= & \kappa^{i} \pi_{t-1}^{i}+\beta E_{t}\left\{\pi_{t+1}^{i}\right\}-\kappa^{i} \beta E_{t-1}\left\{\pi_{t}^{i}\right\} \\
& +\lambda \kappa^{i} \alpha \Delta s_{t}^{i}-\lambda \kappa^{i} \Delta a_{t}^{i}+\lambda(1+\phi) \tilde{y}_{t}^{i}-\frac{\lambda \chi}{1-\chi} \tilde{f}_{t}^{i} .
\end{aligned}
$$

Since domestic policy depends on union-wide decision making, one can combine (31), (32) and the fact that inflation differentials are inversely proportional to productivity growth differentials ${ }^{17}$, to obtain an equation that determines the output gap differentials in terms of fiscal gap differentials and changes in inflation differentials:

$$
\begin{aligned}
\Delta \tilde{y}_{t}^{i}-\Delta \tilde{y}_{t}^{\star} & =\frac{\chi}{1-\chi}\left(\Delta \tilde{f}_{t}^{i}-\Delta \tilde{f}_{t}^{\star}\right)-\left[\Delta s_{t}^{i}+\left(\Delta a_{t}^{i}-\Delta a_{t}^{\star}\right)\right] \\
& =\frac{\chi}{1-\chi}\left(\Delta \tilde{f}_{t}^{i}-\Delta \tilde{f}_{t}^{\star}\right)-\left[\left(\pi_{t}^{i}-\pi_{t}^{\star}\right)+\left(\Delta a_{t}^{i}-\Delta a_{t}^{\star}\right)\right]
\end{aligned}
$$

The previous two expressions describe the dynamics of domestic price level, output gap, and fiscal gap, given the aggregate variables determined by union-wide policy. They make clear that the trade-off is twofold.

Consider first the situation where real wages are fully flexible, i.e. $\kappa^{i}=0$. Then, equation (44) describing the behavior of the price level, implies that by closing the output and fiscal gap at all times, the price level is fully stabilized. However, equation (45) states that, given union-wide policy and in the presence of asymmetric productivity shocks, closing gap variables requires adjustment in terms of trade and, hence, in domestic price level (or vice versa). Since symmetric shifts to technology, however, imply inflation differentials to be inversely proportional to the productivity growth differentials, no further adjustment in terms of trade (or in the domestic price level) is required while output and fiscal gaps are closed.

Things differ substantially if real wage rigidities are present. It is easily seen from (44) that closing the output and fiscal gap at all times does no longer imply full price level stability, even if shocks are purely symmetric. To understand the basic source of this trade-off, consider again the economy's factor price frontier in 36 . Note that under flexible wages a sudden shift in domestic productivity leads to an increase in real wages. If real wages are sticky, a shock in domestic productivity also leads to a decline in real marginal cost:18. Obviously, the higher the real wage sluggishness, the higher the decrease in real marginal costs. It is seen in a previous section that the NKPC provides a direct

\footnotetext{
${ }^{17}$ That is, $\pi_{t}^{i}-p i_{t}^{\star}=-\left(\Delta a_{t}^{i}-\Delta a_{t}^{\star}\right)$. The derivation of this result can be found in the appendix.

${ }^{18}$ This is because domestic authorities cannot avoid that the terms of trade adjust inefficiently.
} 
channel of real marginal costs translate into the aggregate domestic inflation. The dynamic relationship implied by (35) makes clear that the more real marginal costs decrease, the more the price level is under (downward) pressure. To grasp this point more precisely, it can be seen from (44) that an increasing pressure on the price level (and, hence, on terms of trade) can only be absorbed by an increasing output relative to its efficient outcome ${ }^{19}$, To conclude, in the presence of real wage rigidities in country $i$, even given symmetric shocks to technology, stabilizing the price level and gap variables simultaneously is not possible.

Furthermore, equation (44) implies that, given $\kappa^{i}>0$, a change in the output gap, even if purely transitory, has a persistent impact on the domestic inflation. As aforementioned, the rationale for this phenomena is considerably simple: Any change in the workers' reservation wage resulting from a change in output (and thus a change in employment), will affect the real wage (and hence real marginal costs) only gradually, with that effect outliving the eventual return of output to its natural level. To illustrate this point, note that one can write the NKPC in (44) as:

$$
\pi_{t}^{i}=\tilde{x}_{1}^{i} \pi_{t-1}^{i}+\tilde{x}_{2}^{i} E_{t}\left\{\pi_{t+1}^{i}\right\}+\tilde{x}_{3}^{i}\left(\pi_{t}^{i}-E_{t-1}\left\{\pi_{t}^{i}\right\}\right)+\tilde{x}_{4}^{i} \Delta s_{t}^{i}-\tilde{x}_{5}^{i} \Delta a_{t}^{i}+\tilde{x}_{6}^{i} \tilde{y}_{t}^{i}-\tilde{x}_{7}^{i} \tilde{f}_{t}^{i},
$$

where $\tilde{x}_{1}^{i} \equiv \frac{\kappa^{i}}{1+\kappa^{i} \beta}, \tilde{x}_{2}^{i} \equiv \frac{\beta}{1+\kappa^{i} \beta}, \tilde{x}_{3}^{i} \equiv \frac{\kappa^{i} \beta}{1+\kappa^{i} \beta}, \tilde{x}_{4}^{i} \equiv \frac{\lambda \kappa^{i} \alpha}{1+\kappa^{i} \beta}, \tilde{x}_{5}^{i} \equiv \frac{\lambda \kappa^{i}}{1+\kappa^{i} \beta}, \tilde{x}_{6} \equiv \frac{\lambda(1+\phi)}{1+\kappa^{i} \beta}$, and $\tilde{x}_{7}^{i} \equiv \frac{\lambda}{1+\kappa^{i} \beta} \frac{\gamma}{1-\gamma}$. Obviously, the weight attached to lagged and expected inflation depends on the degree of real wage rigidity: the higher $\kappa^{i}$, the higher the weight on lagged inflation and the lower the one associated with expected inflation.

Notice that the latter expression is very similar to a hybrid version of the NKPC recently discussed in the literature 20

\footnotetext{
${ }^{19}$ Without loss of generality, I here abstract from fiscal policy as a stabilization instrument set $\tilde{f}_{t}^{i}=0$. In the next section the role of fiscal policy is discussed in detail.

${ }^{20}$ The reason for a number of researchers to recently consider a hybrid version of the NKPC is the striking empirical limitations of the standard one, which has a similar form to $\pi_{t}=\beta E_{t}\left\{\pi_{t+1}\right\}+\lambda \nu \tilde{y}_{t}$ (where the variables and parameters are defined as above and $\nu$ is the output elasticity of real marginal costs). As argued in Galí and Gertler (1999), an essential problem is that the standard NKPC implies that inflation should lead the output gap over the cycle, in the sense that a rise (decline) in current inflation should signal a subsequent rise (decline) in the output gap. This is in stark contrast to empirical findings. For more recent contributions on the empirical assessment of hybrid NKPC, see Sbordone (2005), Galí, Gertler and Lopez-Salido (2005), Lindé (2005) and Rudd and Whelan (2005).
} 


\subsubsection{Union-wide Trade-offs}

In order to derive the implications for union-wide policies, I integrate (44) over $i$, which yields the aggregate NKPC for the union as a whole

$$
\pi_{t}^{\star}=\kappa^{\star} \pi_{t-1}^{\star}+\beta E_{t}\left\{\pi_{t+1}^{\star}\right\}-\kappa^{\star} \beta E_{t-1}\left\{\pi_{t}^{\star}\right\}-\lambda \kappa^{\star} \Delta a_{t}^{\star}+\lambda(1+\phi) \tilde{y}_{t}^{\star}-\frac{\lambda \chi}{1-\chi} \tilde{f}_{t}^{\star} .
$$

Second, one can use (34) to derive an expression that determines the union-wide output gap:

$$
\begin{aligned}
\tilde{y}_{t}^{\star} & =E_{t}\left\{\tilde{y}_{t+1}^{\star}\right\}-(1-\chi)\left(r_{t}^{\star}-E_{t}\left\{\pi_{t+1}^{\star}\right\}-\overline{r r}_{t}^{\star}\right)-\chi E_{t} \Delta \tilde{g}_{t+1}^{\star} \\
& =\frac{\chi}{1-\chi} \tilde{f}_{t}^{\star}-\left(r_{t}^{\star}-E_{t}\left\{\pi_{t+1}^{\star}\right\}-\bar{r} r_{t}^{\star}\right)+E_{t}\left\{\tilde{y}_{t+1}^{\star}\right\}-\frac{\chi}{1-\chi} E_{t}\left\{\tilde{f}_{t+1}^{\star}\right\},
\end{aligned}
$$

where $\overline{r r}_{t}^{\star}$ is the natural rate of interest, given by:

$$
\begin{aligned}
\overline{r r}_{t}^{\star} & =\rho+\frac{1}{1-\chi}\left(E_{t}\left\{\Delta \bar{y}_{t+1}^{\star}-\chi E_{t}\left\{\bar{g}_{t+1}^{\star}\right\}\right)\right. \\
& =\rho+E_{t}\left\{\Delta \bar{y}_{t+1}^{\star}\right\} \\
& =\rho+\left\{E_{t} \Delta a_{t+1}^{\star}\right\} .
\end{aligned}
$$

The NKPC in (47) and the DIS equation in (48) now fully describe the dynamics of aggregate inflation and output gap, given a monetary policy rule in the form of a nominal interest rate and a fiscal policy determining the fiscal gap for all member states.

Since each member country is assumed to be of measure zero, a domestic shock to technology has no effect on union-wide dynamics. Thus, as long as a country-specific shock is indiosyncratic, it does not affect aggregate technology, i.e. $a^{\star}$ remains at a constant (zero) level. As a consequence, closing union-wide gap variables is always feasible (and optimal) and goes along with a constant aggergate inflation. This result is standard in basic NK business cycle theory and is by Blanchard and Galí (2007) referred to as "divine coincidence". In reality, central banks often perceive a trade-off between stabilizing the price level and stabilizing the gap between actual output and desired output. However, note that even in the presence of an union-wide shift to technology this "divine coincidence" still holds but only conditional on fully felxible real wages. This result corresponds to the findings of Galí and Monacelli (2008).

Given a sluggish adjustments of real wages and an union-wide shock to technology, the NKPC in (47) implies that there is not an exact relation anymore, however complex, between aggregate inflation and the welfare-relevant union-wide output gap. However, note that if either prices or wages are fully flexible the "divine coincidence" is valid again. 
This is a result already shown by Erceg, Henderson, and Levin (2000) and Christiano, Eichenbaum, and Evans (2005) for a single closed country's economy with staggered nominal wage setting ${ }^{21}$. This can be easily explained by considering the union as a single closed economy: Note that zero variance in inflation implies that firms are always on their optimal labor demand schedules at all time. Since more flexibility in the real wages implies that the people's labor supply schedule is closer to the firms' optimal demand for labor, one has less variations in inflation and gap variables. To see this formally, consider the union-wide NKPC in (42). The smaller $\kappa^{\star}$, the smaller the trade-off. Alternatively, if prices adjust more freely firms can be kept closer to their optimal labor demand schedules. Technically spoken, a decrease in $\theta$ causes a decrease in $\lambda$. Again, the smaller $\lambda$, the smaller the trade-off considered above.

Given the situation of real wage and price rigidity and an aggregate shift in productivity, it can be easily seen that whatever policy is conducted, aggregate welfare losses have to be accepted. Thus, there is no way to stabilize both, inflation and gap variables, and the common central bank faces a clear trade-off. I find below that the welfare optimal policy allows variations in all three target variables.

\subsection{Optimal Monetary and Fiscal Policy Design}

The aim of this paper is to derive optimal monetary and fiscal policy rules for a currency union. Optimality is measured in terms of welfare. Thus, the first step in deriving such optimal policies should be to characterize the welfare to be maximized. In the previous section, I defined welfare as the aggregate households' utility. Since there are no (static) distortions in the steady state (given the subsidy is set correctly), the policymakers' (perfect coordinated fiscal and monetary authorities) joint objective is the same as in the social planner's problem. The only difference is that political authorities are subject to the equilibrium conditions for any individual member country, as discussed above. In the following I derive optimal policies for domestic and union-wide authorities under full commitment and full coordination 22

\footnotetext{
${ }^{21}$ Basically, the implication for the union as a whole are closely related to those of a closed economy studied in Blanchard and Galí (2007).

${ }^{22}$ The term "optimal" - at least seen from an union-wide perspective - already implies somewhat perfect coordinated (and committed) policies. Moreover, if non-coordinated authorities are considered, the task of deriving optimal policies becomes numerically more complex. In this regard, a closer examination of Forlati (2008) is instructive.
} 
As the analysis is based on gap variables instead of real variables, a welfare objective based on $\pi_{t}^{i}, \tilde{y}_{t}^{i}$, and $\tilde{f}_{t}^{i}$ for all $i \in(0,1)$ and $t=0,1,2, \ldots$ has to be derived. A closer look at the derivation of a purely quadratic loss function, which represents the approximated (up to second order) welfare losses due to variations from the efficient (steady state) level of inflation, output gap, and fiscal gap is let to the appendix. It can be shown that the objective of the coordinated monetary and fiscal authorities is to minimize the welfare losses, which can be expressed in terms of inflation and gap variables as:

$$
\mathbb{W} \mathbb{L}=\frac{1}{2} \sum_{t=0}^{\infty} \beta^{t} \int_{0}^{1}\left(\frac{\epsilon}{\lambda}\left(\pi_{t}^{i}\right)^{2}+(1+\phi)\left(\tilde{y}_{t}^{i}\right)^{2}+\frac{\chi}{1-\chi}\left(\tilde{f}_{t}^{i}\right)^{2}\right) d i+t . i . p+\left\|\mathcal{O}\left(\zeta_{t}\right)\right\|^{3},(
$$

where t.i.p denotes terms independent from policy and $\left\|\mathcal{O}\left(\zeta_{t}\right)\right\|^{3}$ are terms of higher order.

There are several important qualitative features which are evidently seen from (49). The welfare cost of variation in the price level is increasing with the substitutability across varieties produced within any country and the average duration of prices. Note that a rise in the price level in, say country $i$, follows a decline in the effective terms of trade. Therefore, the higher $\epsilon$, the higher the cost of inflation. Again, welfare is independent of variation in the price level, only in the special case of complectly flexible prices. This result can naturally be comprehended by regarding the dynamics of inflation determined by the NKPC in (35).

Moreover, it can be perceived that the cost of output deviation from its welfare optimal level is decreasing with labor supply elasticity, i.e $1 / \phi$. Notice that an increase in output gap implies an increase in employment relative to its welfare optimal level. Thus, the higher the labor supply elasticity, the less costly a variation in employment and, hence, in output. Finally, it should be intuitively clear that the cost of variation in the fiscal stance depends positively on the weight attached to public consumption.

\subsubsection{The Policy Makers' Problem}

As abovementioned, the policy makers' task is to minimize the welfare losses for all member states $i \in(0,1)$ and all periods of time $t=0,1,2, \ldots$, subject to the single country equilibrium conditions (44) and (45), as well as the "aggregation" constraints:

$$
\pi_{t}^{\star}=\int_{0}^{1} \pi_{t}^{i} d i, \quad \tilde{y}_{t}^{\star}=\int_{0}^{1} \tilde{y}_{t}^{i} d i, \quad \tilde{f}_{t}^{\star}=\int_{0}^{1} \tilde{f}_{t}^{i} d i .
$$

To approximate welfare losses due to variations in the policy makers' target variables, a purely quadratic loss function is considered. That is, the policy makers' objective has a 
clear functional form given by:

$$
\mathbb{L}=\frac{1}{2} \sum_{t=0}^{\infty} \beta^{t} \int_{0}^{1}\left(\frac{\epsilon}{\lambda}\left(\pi_{t}^{i}\right)^{2}+(1+\phi)\left(\tilde{y}_{t}^{i}\right)^{2}+\frac{\chi}{1-\chi}\left(\tilde{f}_{t}^{i}\right)^{2}\right) d i .
$$

Now, one can state the common policy problem in the following Lagrangian:

$$
\begin{aligned}
\mathcal{L}= & \sum_{t=0}^{\infty} \int_{0}^{1}\left\{\frac{1}{2} \beta^{t}\left(\frac{\epsilon}{\lambda}\left(\pi_{t}^{i}\right)^{2}+(1+\phi)\left(\tilde{y}_{t}^{i}\right)^{2}+\frac{\chi}{1-\chi}\left(\tilde{f}_{t}^{i}\right)^{2}\right)\right. \\
& +\psi_{\pi, t}^{i}\left(\pi_{t}^{i}-\kappa^{i} \pi_{t-1}^{i}-\beta E_{t}\left\{\pi_{t+1}^{i}\right\}+\beta \kappa^{i} E_{t-1}\left\{\pi_{t}^{i}\right\}-\lambda \kappa^{i} \alpha \Delta s_{t}^{i}\right. \\
& \left.\quad+\lambda \kappa^{i} \Delta a_{t}^{i}-\lambda(1+\phi) \tilde{y}_{t}^{i}+\frac{\lambda \chi}{1-\chi} \tilde{f}_{t}^{i}\right) \\
& +\psi_{y, t}^{i}\left(\Delta \tilde{y}_{t}^{i}-\Delta \tilde{y}_{t}^{\star}-\frac{\chi}{1-\chi}\left(\Delta \tilde{f}_{t}^{i}-\Delta \tilde{f}_{t}^{\star}\right)+\pi_{t}^{i}-\pi_{t}^{\star}+\Delta a_{t}^{i}-\Delta a_{t}^{\star}\right) \\
& +\psi_{\pi, t}^{\star}\left(\pi_{t}^{\star}-\int_{0}^{1} \pi_{t}^{i} d i\right) \\
& +\psi_{y, t}^{\star}\left(\tilde{y}_{t}^{\star}-\int_{0}^{1} \tilde{y}_{t}^{i} d i\right) \\
& \left.+\psi_{f, t}^{\star}\left(\tilde{f}_{t}^{\star}-\int_{0}^{1} \tilde{f}_{t}^{i} d i\right)\right\} d i,
\end{aligned}
$$

where $\psi_{\pi, t}^{i}, \psi_{y, t}^{i}, \psi_{\pi, t}^{\star}, \psi_{y, t}^{\star}$, and $\psi_{f, t}^{\star}$ denote the discounted Lagrange multipliers associated with the constraints in (44), 45), and (50).

Minimizing 52 with respect to $\left\{\pi_{t}^{i}, \tilde{y}_{t}^{i}, \tilde{f}_{t}^{i}\right\}$ for all $i \in(0,1)$ and all $t=0,1,2, \ldots$ leads to the following optimality conditions:

$$
\begin{array}{ll}
\frac{\partial \mathcal{L}}{\partial \pi_{t}^{i}}: & \frac{\epsilon}{\lambda} \pi_{t}^{i}+\left(\left(1+\kappa^{i} \beta\right)-\kappa^{i} \beta L^{-1}-L\right) \psi_{\pi, t}^{i}+\psi_{y, t}^{i}-\psi_{\pi, t}^{\star}=0 \\
\frac{\partial \mathcal{L}}{\partial \tilde{y}_{t}^{i}}: & (1+\phi) \tilde{y}_{t}^{i}-\lambda(1+\phi) \psi_{\pi, t}^{i}+\left(1-\beta L^{-1}\right) \psi_{y, t}^{i}-\psi_{y, t}^{\star}=0 \\
\frac{\partial \mathcal{L}}{\partial \tilde{f}_{t}^{i}}: & \frac{\chi}{1-\chi} \tilde{f}_{t}^{i}+\frac{\lambda \chi}{1-\chi} \psi_{\pi, t}^{i}-\frac{\chi\left(1-\beta L^{-1}\right)}{1-\chi} \psi_{y, t}^{i}-\psi_{f, t}^{\star}=0 \\
\frac{\partial \mathcal{L}}{\partial \pi_{t}^{\star}}: & -\int_{0}^{1} \psi_{y, t}^{i} d i+\psi_{\pi, t}^{\star}=0 \\
\frac{\partial \mathcal{L}}{\partial \tilde{y}_{t}^{\star}}: & -\left(1-\beta L^{-1}\right) \int_{0}^{1} \psi_{y, t}^{i} d i+\psi_{y, t}^{\star}=0 \\
\frac{\partial \mathcal{L}}{\partial \tilde{f}_{t}^{\star}}: & \frac{\chi\left(1-\beta L^{-1}\right)}{1-\chi} \int_{0}^{1} \psi_{y, t}^{i} d i+\psi_{f, t}^{\star}=0,
\end{array}
$$

\subsubsection{Union-wide Equilibrium Dynamics under the Optimal Policy}

In order to derive the implied path for $\pi_{t}^{\star}, \tilde{y}_{t}^{\star}$, and $\tilde{f}_{t}^{\star}$, one can integrate 53) over $i$ and by combining the resulting expression with $(56)$ one gets:

$$
\frac{\epsilon}{\lambda} \pi_{t}^{\star}+\left(\left(1+\kappa^{\star} \beta\right)-\kappa^{\star} \beta L^{-1}-L\right) \int_{0}^{1} \psi_{\pi, t}^{i} d i=0 .
$$


Similarly, integrating (54) over $i$ and combining with (57) yields:

$$
(1+\phi) \tilde{y}_{t}^{\star}-\lambda(1+\phi) \int_{0}^{1} \psi_{\pi, t}^{i} d i=0
$$

Now, by combining the latter two equations, one can derive a monetary policy rule that specifies a condition to be fulfilled by the central bank's target variables:

$$
\pi_{t}^{\star}=-\frac{1+\kappa^{\star} \beta}{\epsilon} \tilde{y}_{t}^{\star}+\frac{\kappa^{\star} \beta}{\epsilon} E_{t}\left\{\tilde{y}_{t+1}^{\star}\right\}+\frac{1}{\epsilon} \tilde{y}_{t-1}^{\star}
$$

for all $t=0,1,2, \ldots$ The previous equation has a simple interpretation: In the face of disinflationary pressure due to a shift in (aggregate) technology, the central bank must respond by driving the union-wide output above its efficient level, thus creating a positive output gap, to damp the downward pressure on the union's price level. Of course, the pressure on the price level increases with $\kappa^{\star}$ and so does the output gap created by the central bank. By combining (58) with (60), one gets the following equation, describing the dynamic behavior of aggregate gap variables:

$$
\tilde{f}_{t}^{\star}=-\tilde{y}_{t}^{\star},
$$

for all $t=0,1,2, \ldots$ It is evidently seen, that the aggregate fiscal stance remains at its efficient level at all time. Since fiscal policy is not a valid instrument to stabilize the union-wide economy, the common central bank takes over this role. Technically, one could combine (47), 61), and (62) to describe the target variables' dynamics under the optimal policy.

The equilibrium behavior of the union-wide economy under the optimal policy as a response to a sudden shift in aggregate technology are illustrated in figures 1-2, As aforementioned, there is no way to stabilize inflation, output gap and fiscal gap simultaneously. This result is contrary to a lot of existing literature on optimal monetary (and fiscal) policy. Moreover, its policy implication, namely accept variations in the price level and give some weight to output stabilization, contradicts the actual policy of the ECB, which rather pursues a policy of price stability (also in the presence of EMU-wide shocks). However, it is important to sharply distinguish between aggregate and country-specific indiosyncratic shocks to technology. While the first one results in an active role of monetary policy, the latter one still yields to strict inflation targeting as an optimal monetary policy rule.

The optimal targeting rule for monetary policy derived above, implicitly assumes that the central bank can choose its desired level of inflation, output gap, and fiscal gap. Of course, in practice the policy maker cannot set all three target variables simultaneously. 
One possibility to achieve the desired outcome anyway, is to set its political instrument, namely the nominal interest rate such that the opitmal allocation is achieved. If real wages are fully flexible, the central bank faces no trade-off between stabilizing inflation or output around potential. Regarding the DIS in terms of gap variables in $(48)$ indicates that the interest rate that supports the efficient allocation is always equal to the natural rate of interest, and which is invariant to monetary policy.

However, if real wages are rigid monetary policy monetary plays a central role for stabilizing the aggregate economy. By combining (48), (61) and 62 it can be seen that in the welfare optimal equilibrium the nominal interest rate then equals:

$$
r_{t}^{\star}=\phi_{y}^{1} \tilde{y}_{t-1}^{\star}+\phi_{y}^{2} E_{t}\left\{\tilde{y}_{t+1}^{\star}\right\}+\phi_{\pi}^{1} \pi_{t}^{\star}+\phi_{\pi}^{2} E_{t}\left\{\pi_{t+1}\right\}+\bar{r} r_{t}^{\star},
$$

for all $t=0,1,2, \ldots$ and where $\phi_{y}^{1} \equiv-\frac{\chi}{1+\kappa^{\star} \beta}, \phi_{y}^{2} \equiv \chi-\frac{\chi \kappa^{\star} \beta}{1+\kappa^{\star} \beta}, \phi_{\pi}^{1} \equiv \frac{\chi \epsilon}{1+\kappa^{\star} \beta}$, and $\phi_{\pi}^{2} \equiv 1$.

\subsubsection{Domestic Equilibrium Dynamics under the Optimal Policy}

First, I will investigate the paths of inflation, output gap and fiscal gap in a member state implied by the optimal policy derived above. For this purpose, note first that (57) together with $(58)$ can be written as:

$$
\psi_{f, t}^{\star}=-\frac{\chi}{1-\chi} \psi_{y, t}^{\star}
$$

Now, combining (54) with (55) and using the latter expression yields:

$$
\lambda \phi \psi_{\pi, t}^{i}=(1+\phi) \tilde{y}_{t}^{i}+\tilde{f}_{t}^{i}
$$

Reconsider that the NKPC for each member state is derived from its basic version in (35). This makes clear that (44) is a binding constraint for the optimization task in (52) as long as $\lambda>0$ and, hence, as long as $\theta>0$ holds. Thus, as long as prices are less than fully flexible, $\psi_{\pi, t}^{i}$ is a positive number strict greater than zero. From this it follows that under the union-wide optimal policy neither $\tilde{y}_{t}^{i}$ nor $\tilde{f}_{t}^{i}$ remain at its efficient level (also when real wages are fully flexible). Second, I derive a dynamic equilibrium of the domestic economy in country $i$. First, one can combine $(53)$ with $(56)$ to get:

$$
\pi_{t}^{i}=-\frac{\lambda}{\epsilon} \psi_{\pi, t}^{i}+\frac{\lambda \kappa^{i} \beta}{\epsilon\left(1+\kappa^{i} \beta\right)} E_{t}\left\{\psi_{\pi, t+1}^{i}\right\}+\frac{\lambda}{\epsilon\left(1+\kappa^{i} \beta\right)} \psi_{\pi, t-1}^{i}-\frac{\lambda}{\epsilon\left(1+\kappa^{i} \beta\right)} \Psi_{\tilde{y}, t}^{i},
$$

where $\Psi_{\tilde{y}, t}^{i} \equiv \psi_{\tilde{y}, t}^{i}-\int_{0}^{1} \psi_{\tilde{y}, t}^{i} d i$. Note that the aggregate multiplier must evolve exogenously from country $i$ 's perspective and, hence, the equilibrium relationship holds for any value of $\int_{0}^{1} \psi_{\tilde{y}, t}^{i} d i$. Similarly, combining 54 with 57 yields:

$$
\tilde{y}_{t}^{i}=\lambda \psi_{\pi, t}^{i}-\frac{1}{1+\phi} \Psi_{\tilde{y}, t}^{i}+\frac{\beta}{1+\phi} E_{t}\left\{\Psi_{\tilde{y}, t+1}^{i}\right\} .
$$


Finally, (55) together with (58) can be written as:

$$
\tilde{f}_{t}^{i}=-\lambda \psi_{\pi, t}^{i}+\Psi_{\tilde{y}, t}^{i}-\beta E_{t}\left\{\Psi_{\tilde{y}, t+1}^{i}\right\} .
$$

Now, I can define a rational expectations equilibrium under union-wide optimal policies for country $i$ as an allocation of $\left\{\pi_{t}^{i}, \tilde{y}_{t}^{i}, \tilde{f}_{t}^{i}, \psi_{\pi, t}^{i}, \Psi_{\tilde{y}, t}^{i}\right\}$ for all $t=0,1,2, \ldots$ that satisfies 44 , (45), 64), 65), and 666).

Note that this description of a rational expectations equilibrium is only valid if, and only if, $\theta>0$. If prices in country $i$ are fully flexible, $\sqrt{63}$ can be written as:

$$
\frac{1}{1+\phi} \tilde{f}_{t}^{i}=-\tilde{y}_{t}^{i}
$$

and combined with (44) and (45) describes the equilibrium dynamics of the domestic economy given flexible prices.

Again, one has to distinguish between asymmetric and symmetric growth in productivity. The equilibrium dynamics for country $i$ in the first scenario are illustrated in figures 3.4. Comparing the results with the optimal policies for the union-wide level, one can asses that the roles of monetary and fiscal policy are reversed (also if real wages are fully flexible). While fiscal policy is not used to stabilize the aggregate economy, monetary policy will not be employed to stabilize the local economies, because it cannot affect crosscountry inflation differentials. Instead, domestic fiscal policy takes this role. The domestic fiscal authority employs the public spending in order to damp domestic deflation. Due to a shock in technology, the domestic price level is under upward pressure, since neither prices nor wages can adjust directly. The domestic fiscal authority employs its fiscal instrument to damp the pressure on the price level. How fiscal policy is conducted depends on the degree of rigidity in prices and real wages. If only prices are less than fully flexible, the rise in productivity must be absorbed via a gradual fall of the price level, with the consequent relative price distortions. Hence, to the extent that the price level reacts gradually, the rise in productivity will be absorbed by a combination of a fall in the output gap and a rise in the fiscal gap. Expanding the fiscal gap is necessary to bring about the demand to accommodate the desired expansion in output. In general, the local fiscal authority necessarily faces a trade-off between accepting movements in inflation on the one hand, and movements in the output and fiscal gap on the other. The higher the degree of price rigidity, the larger the implied fluctuations of both gaps under the optimal policy. As aforementioned, if additionally real wages react inertially, the downward pressure on the 
price level increases. The increasing pressure has to be absorbed by an increase in actual output relative to its efficient level. Again, public spending has to bring about the necessary rise in demand.

Figure 5 illustrates national and union-wide dynamics if technology growth affects all member countries simultaneously. Now, domestic fiscal policies are not needed to adjust cross-country inflation differentials but only absorb the pressure on the price level due to real wage rigidities. This is a crucial insight of this model and an important implication for optimal policiy design in the EMU.

\subsection{Welfare Implications of Alternative Monetary Policy Rules}

While the optimal fiscal policy derived above coresponds -more or less- to the policy conducted by EMU member states, the implication for optimal union-wide monetary policy -in case of symmetric shocks- differs from the actual behavior of the ECB, which policy is rather driven by a (strict) price level target. As abovementioned, if either prices or real wages are flexible, this strategy indeed achieves the pareto optimal allocation. In contrast, I have shown that if both, prices and real wages, adjust sluggishly the pareto optimum is not feasible anymore and the optimal monetary and fiscal policy rules are associated with non-zero variances in all three target variables. According to my analytical results -given the existence of real wage and price rigidities as well as union-wide growth in productivitythe policy conducted by the ECB, however, might not minimize aggregate welfare losses. Thus, it is of interest to compare other simple targeting rules with the optimal one in (61) concerning the union-wide welfare losses accompanied with sticky prices and rigid real wages. While I examine the consequences for different monetary policy rules, I assume that domestic policies are set optimally according the analytcal resulsts derived above.

Following Erceg, Henderson, and Levin (2000), I measure the welfare losses relative to the pareto optimum as a fraction of steady state consumption. That is, the period loss function in (51) is scaled by $U_{C}(\bar{C}, \bar{G}, \bar{N}) \bar{C}$. I calculate welfare costs for varying $\kappa^{\star}$, and $\theta$ the other parameters of the model are set according to the benchmark calibration. The results are presented in tables 1-2. 
Table 1: Welfare Costs of Alternative Monetary Policy Rules for varying $\kappa^{\star}$.

\begin{tabular}{|l|c|c|c|}
\hline$\kappa^{\star}$ & Optimal Policy Rule & Strict Inflation Target & Strict Output Gap Target \\
\hline \hline 0 & 0 & 0 & 0 \\
0.1 & $7.005 \times 10^{-4}$ & $1.543 \times 10^{-3}$ & $2.843 \times 10^{-1}$ \\
0.4 & $1.289 \times 10^{-2}$ & $2.469 \times 10^{-2}$ & 9.62 \\
0.75 & $5.590 \times 10^{-2}$ & $8.679 \times 10^{-2}$ & 160.73 \\
0.99 & $1.136 \times 10^{-1}$ & $1.512 \times 10^{-1}$ & 26253.7 \\
\hline
\end{tabular}

Table 2: Welfare Costs of Alternative Monetary Policy Rules for varying $\theta$

\begin{tabular}{|l|c|c|c|}
\hline$\theta$ & Optimal Policy Rule & Strict Inflation Target & Strict Output Gap Target \\
\hline \hline 0 & 0 & 0 & 0 \\
0.1 & $9.805 \times 10^{-2}$ & $9.874 \times 10^{-2}$ & 2374.3 \\
0.4 & $9.344 \times 10^{-2}$ & $9.874 \times 10^{-2}$ & 265.27 \\
0.75 & $7.249 \times 10^{-2}$ & $9.874 \times 10^{-2}$ & 25.132 \\
0.99 & $5.508 \times 10^{-3}$ & $9.874 \times 10^{-2}$ & $5.885 \times 10^{-1}$ \\
\hline
\end{tabular}

Interestingly, higher nominal inertia is found to be welfare-enhancing in the presence of real wage rigidities. A rationale for this phenomena is quite intuitive: Considering aggregate variables, a higher degree of nominal price rigidity damps the initial consumer goods price response and mitigates the second-round effects from nominal wages on production costs.

However, the main implication of this quantitative experiment is that strict output targeting performs worst in all simulations and that strict inflation targeting is nearly as effective in minimizing welfare losses as the optimal policy. This is not surprising. As discussed above, real wage rigidity causes inertia in marginal costs, and hence, in inflation. To illustrate this point, note that if the central bank conducts strict output targeting with full credibility the NKPC in 47) turns out to be:

$$
\pi_{t}^{\star}=\kappa^{\star} \pi_{t-1}^{\star}+\beta E_{t}\left\{\pi_{t+1}^{\star}\right\}-\kappa^{\star} \beta E_{t-1}\left\{\pi_{t}^{\star}\right\}-\lambda \kappa^{\star} \Delta a_{t}^{\star}
$$

Given an exogenous variation in technology, the inflation will react persistently. These dynamics are illustrated in figures 6.7 .

Similarly, one can analyze the welfare impact of a credible inflation target by writing 
the NKPC as:

$$
\kappa^{\star} \Delta a_{t}^{\star}+(1+\phi) \tilde{y}_{t}^{\star}-\frac{\chi}{1-\chi} \tilde{f}_{t}^{\star}=0 .
$$

It can now easily be seen that the gap variables will not outlive any variation in technology for a long time. Furthermore, it should be clear that the index of price stickiness does not influence the welfare costs anymore - if prices are constant, $\theta$ is redundant. The behavior of the gap variables are illustrated in figures 8.9

At this point one should mention that the optimal targeting rule for monetary policy in (61) has one major drawback: Its properties and parameters depend on the whole model of the economy, including shocks and their stochastic properties, as well as the assumption of an optimal fiscal policy. Hence, it might be a better policy advice for the common central bank to fall back on the "second best" policy rule, namely strict inflation targeting, since the welfare costs might be lower than the ones from a misestimation of the model's parameters or a misspecification of the model itself. It requires no knowledge of the model's parameters but is close to the optimal monetary policy for any variation in the degree of real wage persistence (and the index of price stickiness).

\section{Conclusion}

In this paper I investigate the consequences of real wage rigidities for optimal fiscal and monetary policy in a framework of a multicountry NK model of a currency union, where monetary policy is implemented union-wide by a single central bank, and the fiscal policy is let alone to domestic authorities. I use shocks to productivity growth in order to analyze the equilibrium-dynamics of the domestic and union-wide economy. I assume that a domestic policy decision has very little impact on other member countries, and hence on the (aggregate) union-wide economy. As a consequence, one has to sharply distinguish between country-specific, idiosyncratic and symmetric shifts to productivity. Considering the first scenario, I find that only the domestic country's authorities are facing a tradeoff between stabilzing output around potential and inflation. In the latter setting also the common monetary authority faces a trade-off between stabilizing the aggregate price level and the welfare relevant output. Since marginal costs feed into the determination of prices through the NKPC, I establish a direct channel of real wage rigidities to translate into aggregate inflation dynamics. I find that rigid real wages indeed provide evidence for inflation inertia. 
I derive optimal monetary and fiscal policy from a union-wide perspective in the form of targeting rules. This is done by maximizing the aggregate welfare of the union. Thereby I assume full commitment of the monetary and fiscal authorities. To approximate a welfare objective, a pure quadratic loss function is used, which approximates the welfare losses associated with variations in the target variables. While the fiscal policy cannot be used to stabilize the aggregate economy, the common monetary policy does. Optimal monetary policy suggests that, if nominal and real rigidities are present and the productivity growth is common to all member countries, the central bank stabilizes union-wide economy via a slightly countercyclical policy, to damp the downward pressure on the (aggregate) price level. The countercyclical activity increases with the importance of nominal and real rigidities. The role of fiscal and monetary policy is reversed on the national level. Since domestic authorities cannot avoid that the terms of trade respond inefficiently (because of the impossibility of resorting to nominal exchange rate adjustment), national fiscal policy is justified as a stabilization tool also from a union-wide perspective. However, if shocks are symmetric, not inflation differentials provide a rationale for a countercyclical policy but only the sluggish adjustment of real wages. Again, the pressure on the price level has to be absorbed -to a certain amount- by an expansion in output. To create this output gap, the national government has to bring about the necessary demand. Generally, fiscal policy on domestic level is expansionary also seen from the union's perspective even if the shocks are purely symmetric. Thus external constraints, like the SGP, may be questioned.

By comparing different union-wide monetary policy rules in terms of aggregate welfare losses, I find that strict inflation targeting (conditional on the optimal implementation of fiscal policy from the union's prspective) is close to the optimal monetary policy. Since the optimal rule is somehow complex, strict inflation targeting seems to be a "second best" advice for monetary policy. However, this paper gives first evidence, that basically the ECB should consider the presence of a possible trade-off between stabilizing price level and output gap.

Of course, the present model used for policy analysis is an abstraction of the real world. Many essential features are not included yet, since there is always a trade-off between tractability and realism. Some aspects seem likely to be relevant for the design of policy. I abstract from the need to rely on distortionary taxes, the effects of government debt policies, and the likely existence of non-fully Ricardian behavior on the part of households. Moreover, by relaxing the assumption of perfect risk-sharing, one could possibly generate 
a complementary role for fiscal policy as a cross-country insurance tool. Further research is necessary to include more features related to reality. 


\section{$7 \quad$ Figures}
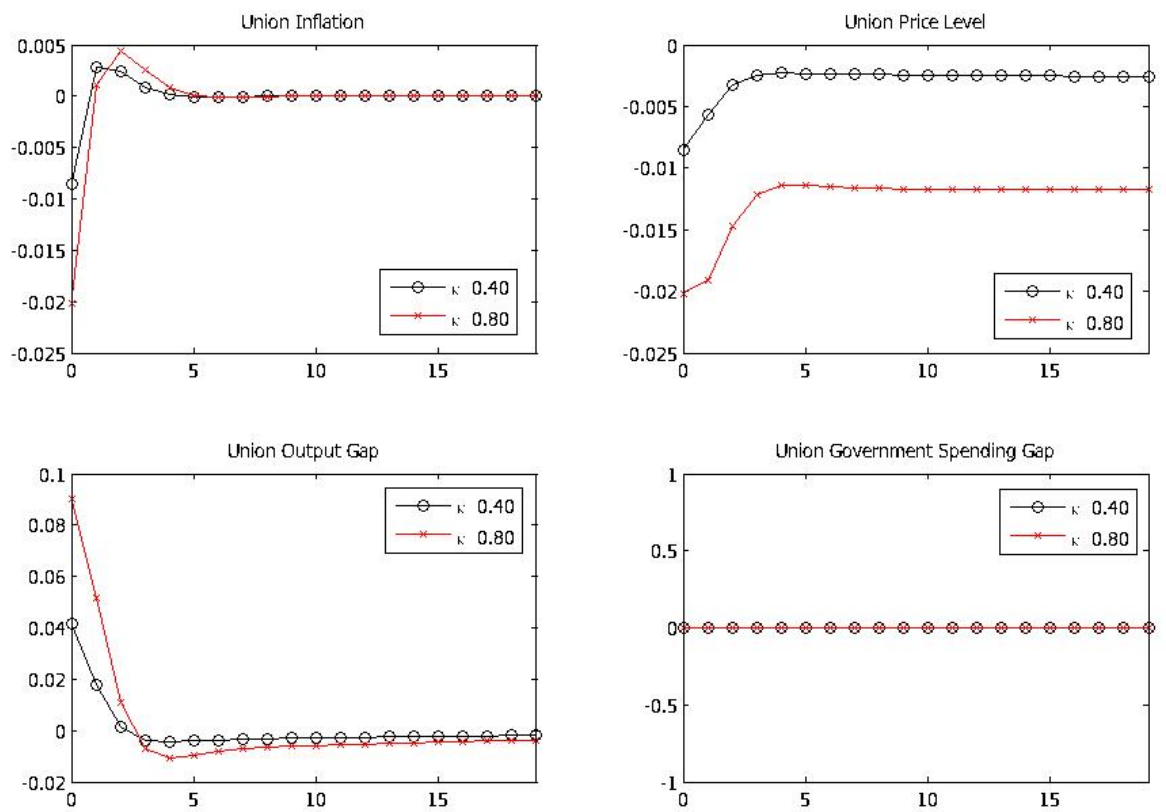

Figure 1: Impulse responses of union-wide variables under the optimal policy mix to an symmetric shock to technology, given the benchmark calibration and variations in $\kappa^{\star}$.
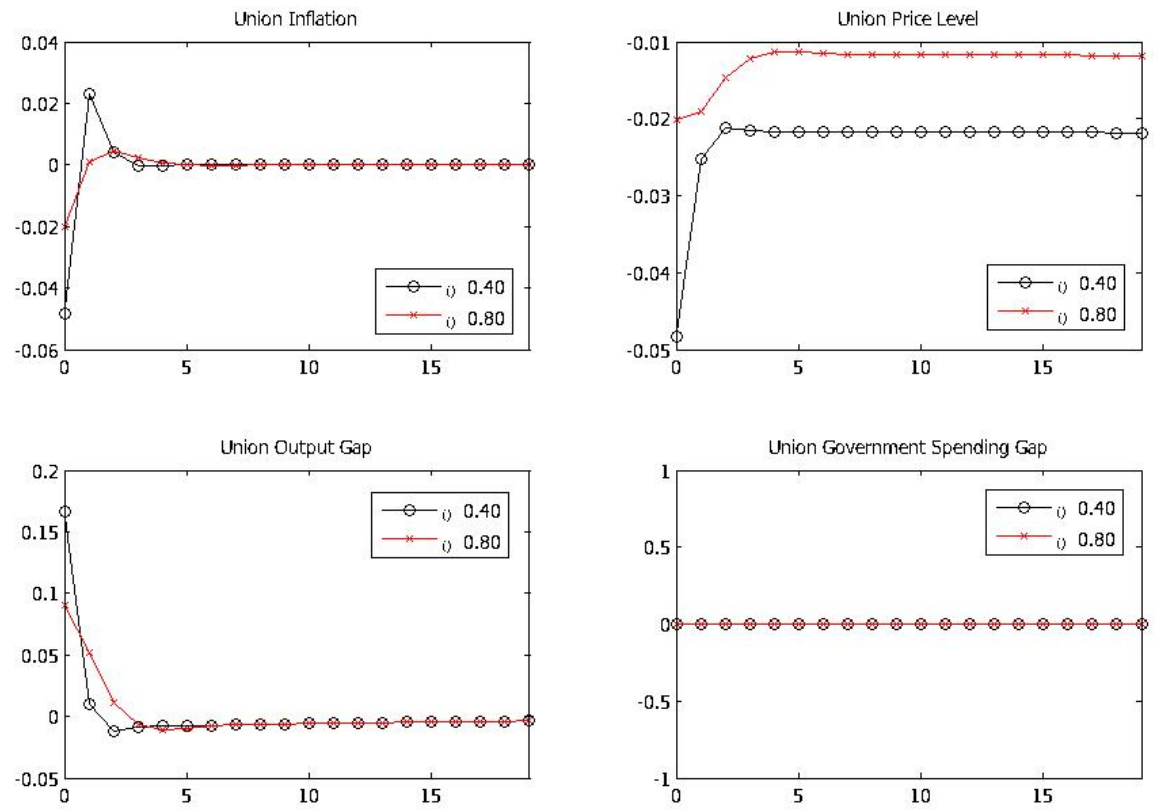

Figure 2: Impulse responses of union-wide variables under the optimal policy mix to an symmetric shock to technology, given the benchmark calibration and variations in $\theta$. 

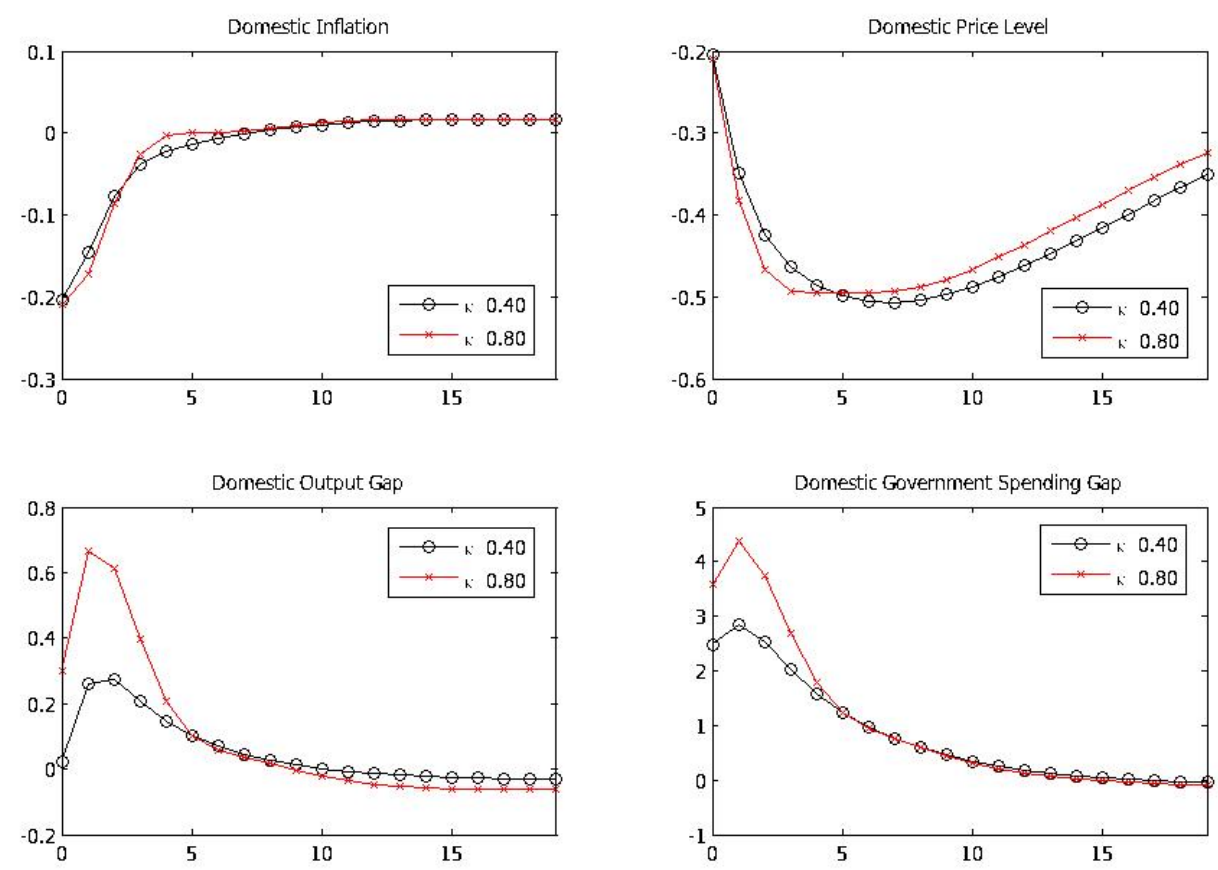

Figure 3: Impulse responses of domestic variables under the optimal policy mix to an idiosyncratic shock to technology, given the benchmark calibration and variations in $\kappa^{i}$.
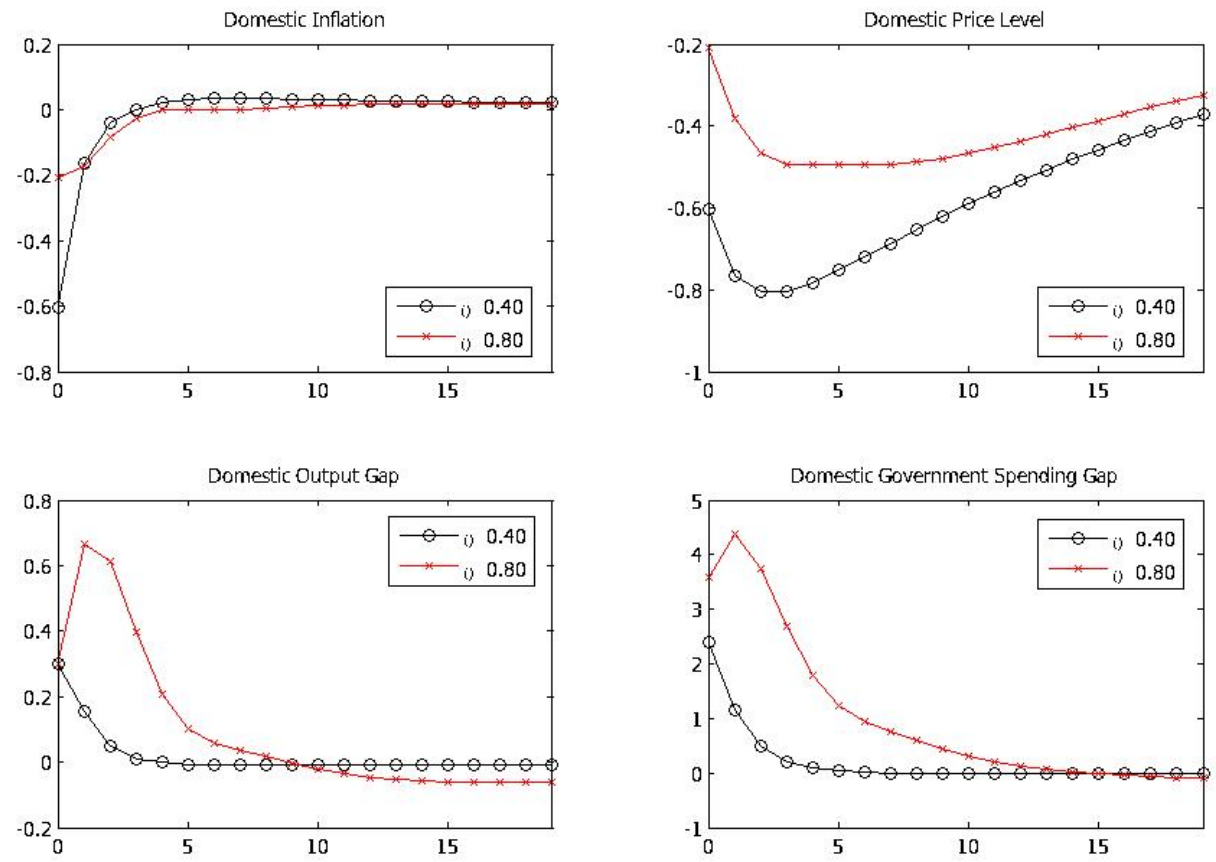

Figure 4: Impulse responses of domestic variables under the optimal policy mix to an idiosyncratic shock to technology, given the benchmark calibration and variations in $\theta$. 

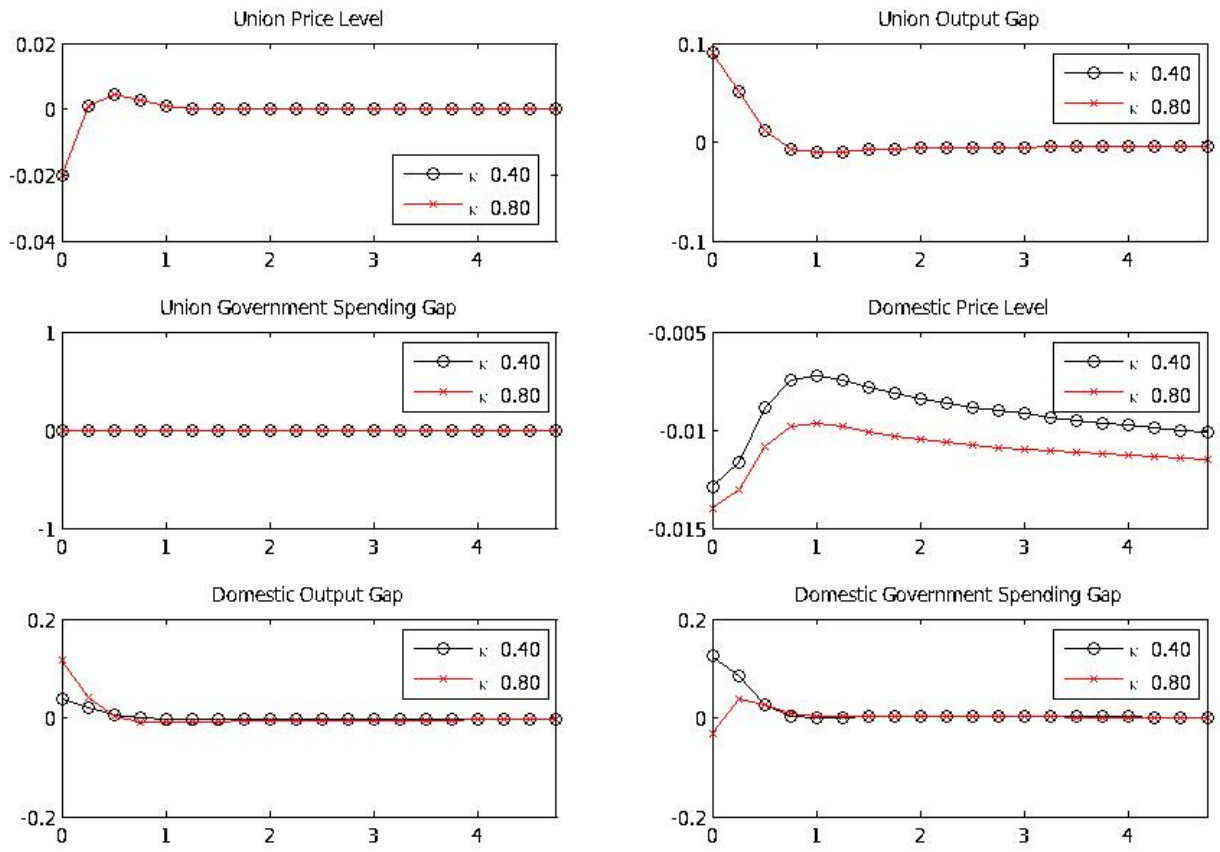

Figure 5: Impulse responses of domestic and union-wide variables under the optimal policy mix to an symmetric shock to technology, given the benchmark calibration and variations in $\kappa^{i}$. 

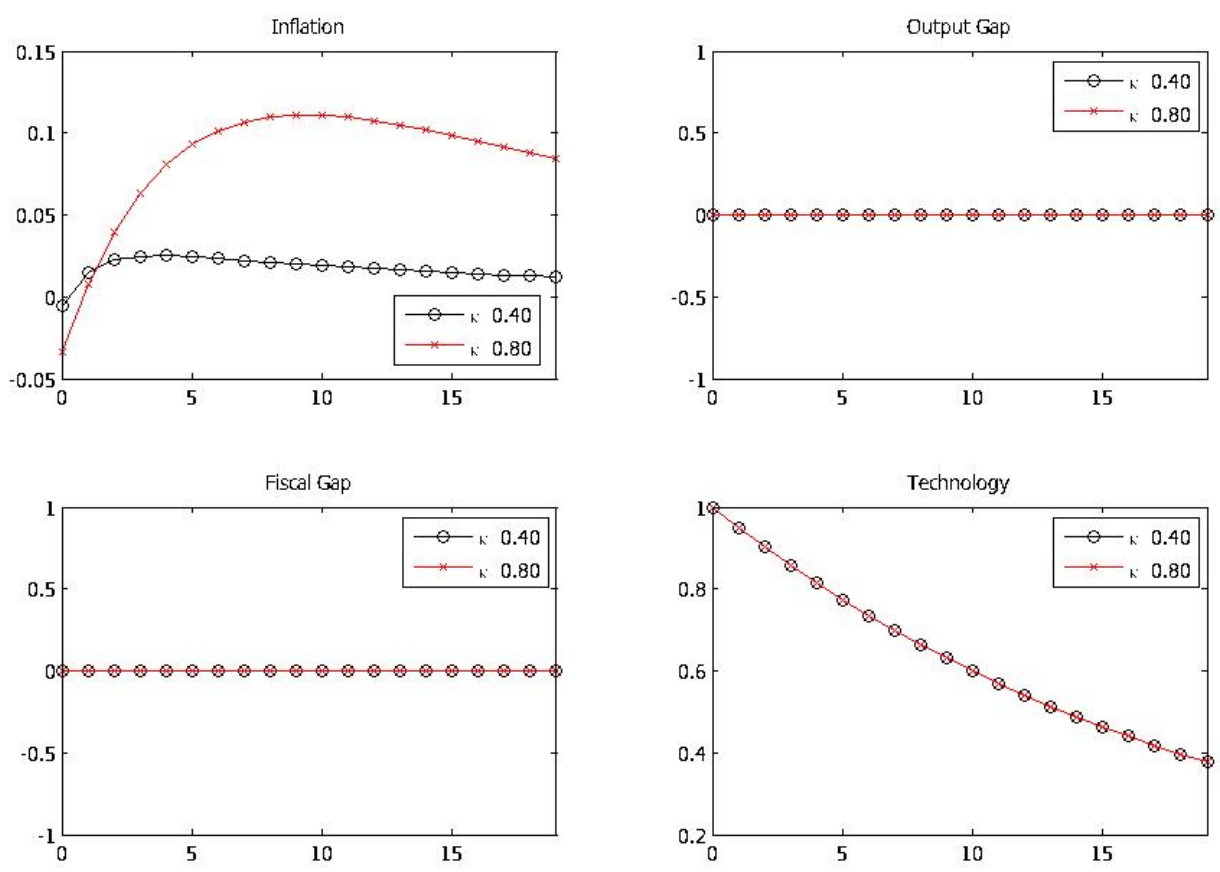

Figure 6: Impulse responses of union-wide variables under a strict output target to an symmetric shock to technology, given the benchmark calibration and variations in $\kappa^{\star}$.
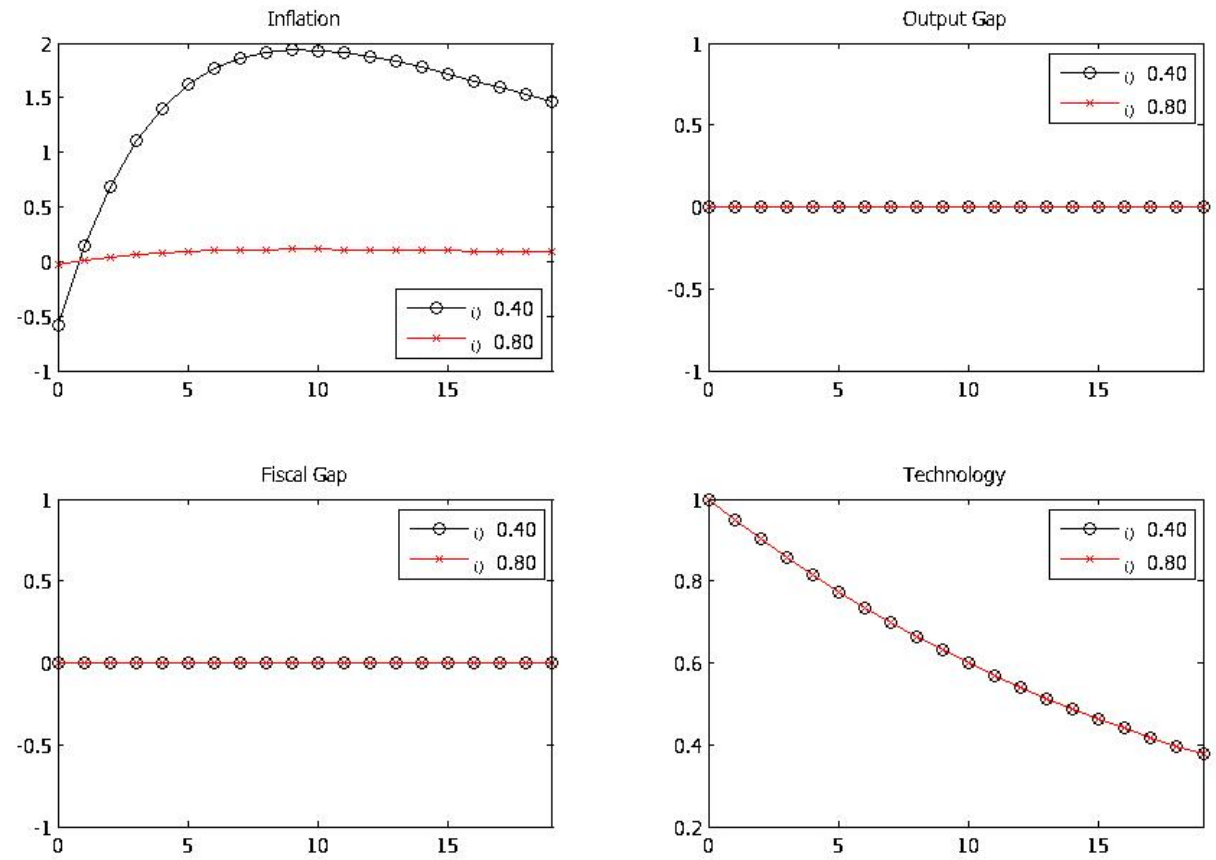

Figure 7: Impulse responses of union-wide variables under a strict output target to an symmetric shock to technology, given the benchmark calibration and variations in $\theta$. 

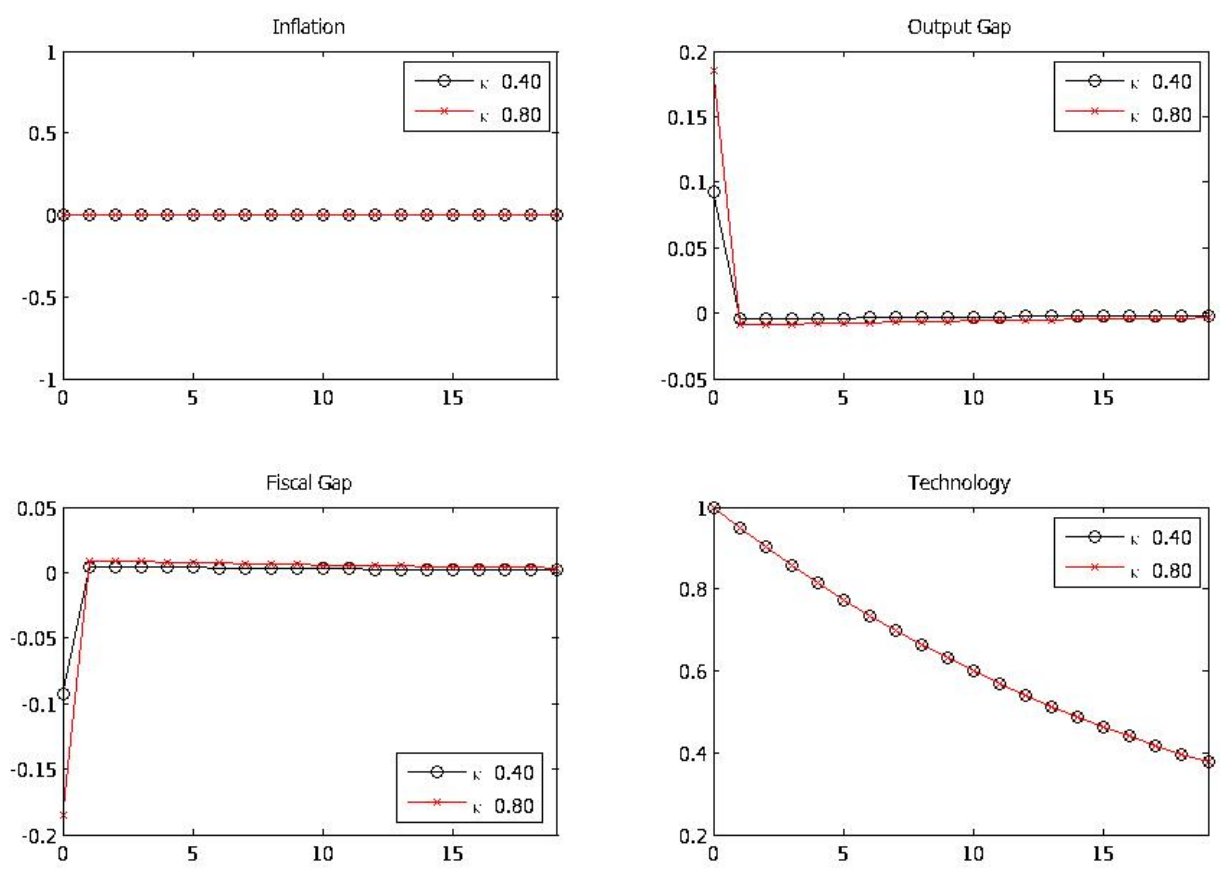

Figure 8: Impulse responses of union-wide variables under a strict inflation target to an symmetric shock to technology, given the benchmark calibration and variations in $\kappa^{\star}$.
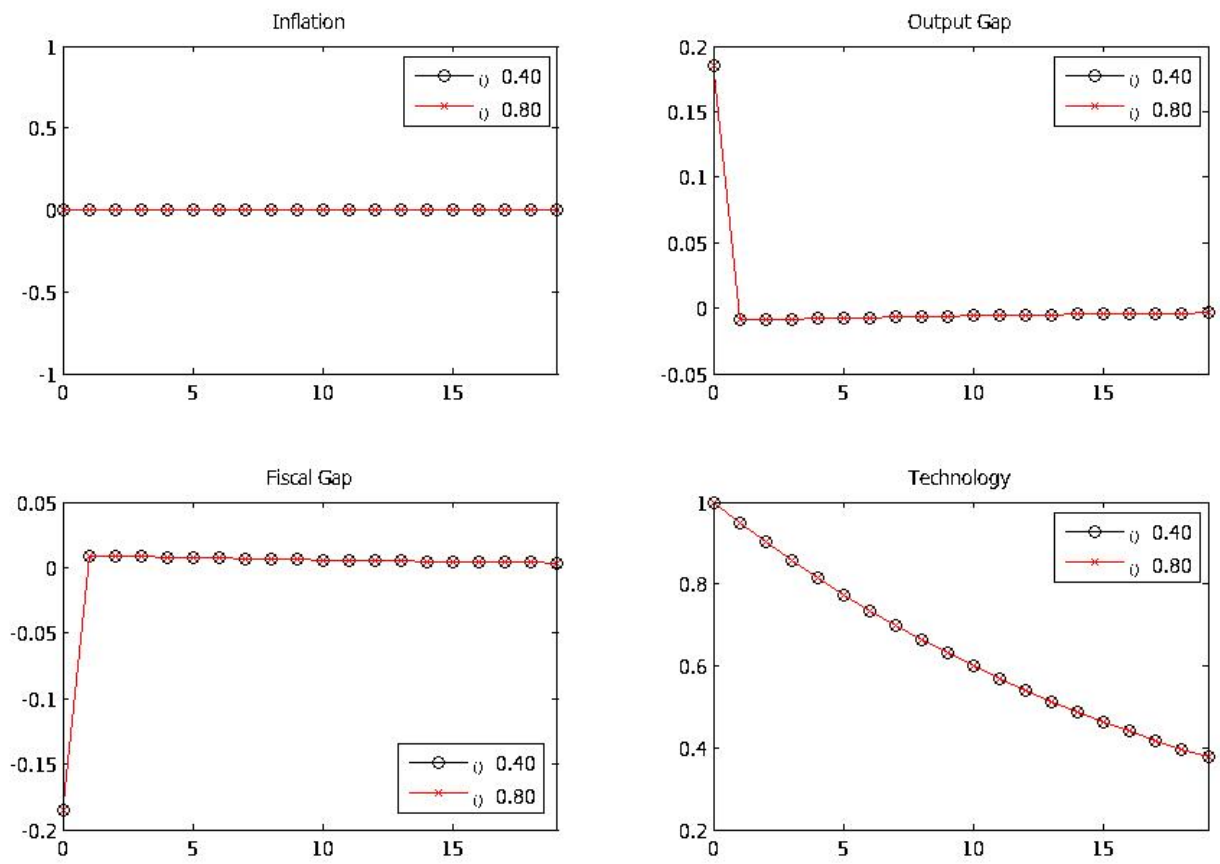

Figure 9: Impulse responses of union-wide variables under a strict inflation target to an symmetric shock to technology, given the benchmark calibration and variations in $\theta$. 


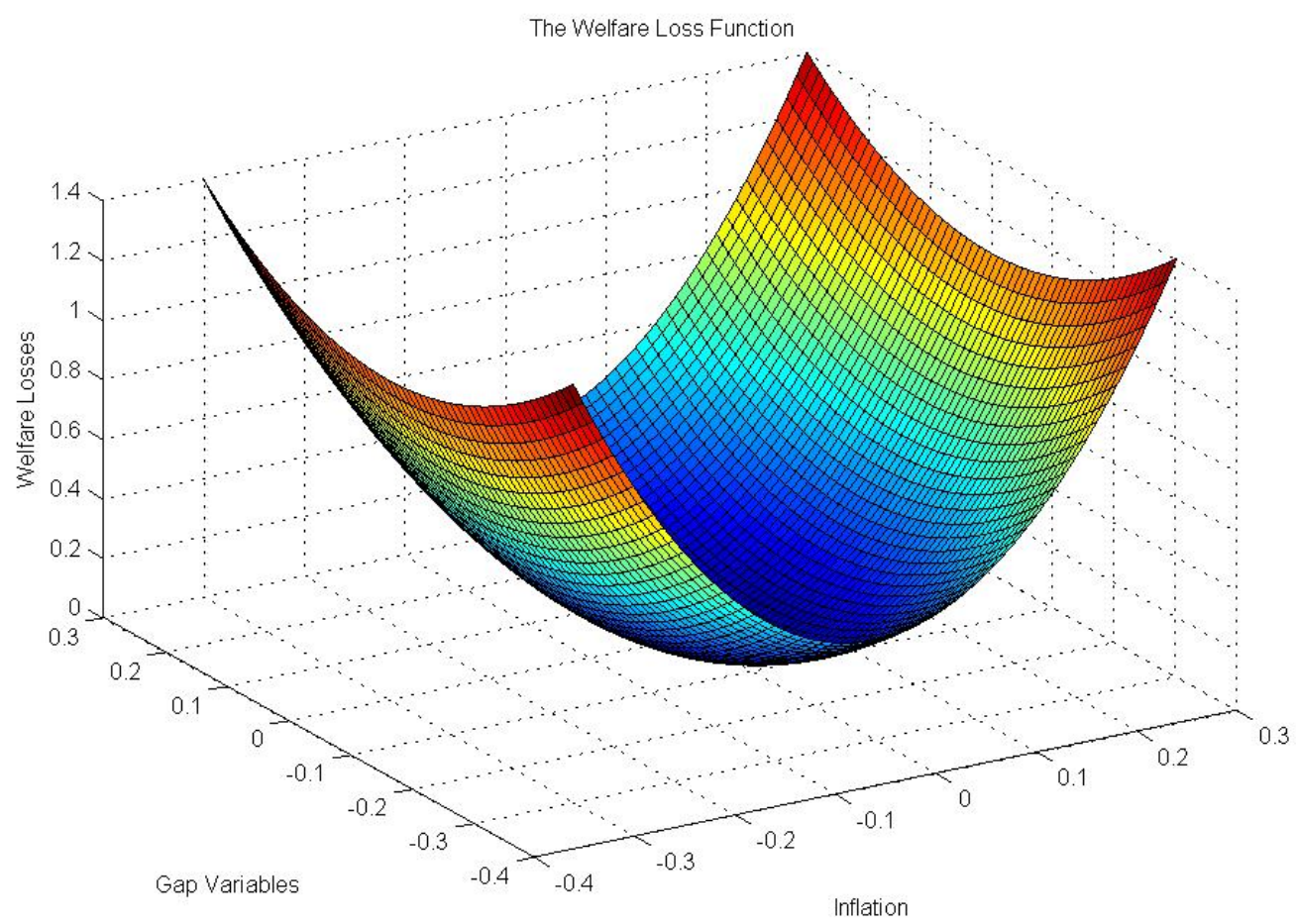

Figure 10: The union-wide welfare loss function under the benchmark calibration. 


\section{References}

[1] Abbritti, M., 2007. "A "Simple" Currency Union Model with Labor Market Frictions, Real Wage Rigidities and Equilibrium Unemployment," HEI Working Papers 092007, Economics Section, The Graduate Institute of International Studies.

[2] Altissimo, F., Ehrmann, M., and Smets, F., 2006. "Inflation persistence and pricesetting behaviour in the euro area - a summary of the IPN evidence," Occasional Paper Series 46, European Central Bank.

[3] Andrés, J., López-Salido, D., and Vallés, J., 2006. "Money in an Estimated Business Cycle Model of the Euro Area," Economic Journal, Royal Economic Society, vol. $116(511)$.

[4] Arpaia, A. and Pichelmann, K., 2007. "Nominal and real wage flexibility in EMU," International Economics and Economic Policy, Springer, vol. 4(3).

[5] Ascari, G. and Merkl, C., 2007. "Real Wage Rigidities and the Cost of Disinflations," IZA Discussion Papers 3049, Institute for the Study of Labor (IZA).

[6] Backus, D., Kehoe, P., and Kydland, F.E., 1992. "International real business cycles," Journal of Political Economy, vol. 101(4).

[7] Bauer, T., Bonin, H. and Sunde, U., 2004. "Real and Nominal Wage Rigidities and the Rate of Inflation: Evidence from West German Microdata," CEPR Discussion Papers 4271, C.E.P.R. Discussion Papers.

[8] Barwell, R. D. and Schweitzer, M. E., 2007. "The Incidence of Nominal and Real Wage Rigidities in Great Britain: 1978-98," Economic Journal, Royal Economic Society, vol. 117(524).

[9] Beetsma, R. and Jensen, H., 2005. "Monetary and fiscal policy interactions in a micro-founded model of a monetary union," Journal of International Economics, Elsevier, vol. 67(2).

[10] Benigno, P., 2004. "Optimal Monetary Policy in a Currency Area," Journal of International Economics, vol. 63. 
[11] Benigno, P. and Woodford, M., 2006. "Linear-Quadratic Approximation of Optimal Policy Problems," NBER Working Papers 12672, National Bureau of Economic Research, Inc.

[12] Benigno, P. and Woodford, M., 2004. "Inflation Stabilization and Welfare: The Case of a Distorted Steady State," NBER Working Papers 10838, National Bureau of Economic Research, Inc.

[13] Benigno, G., and Benigno, P., 2000. "Monetary Policy Rules and the Exchange Rate," Technical Appendix to CEPR Discussion Paper No. 2807.

[14] Bewley, T., 1999. "Why Wages Don̈̈̈ $\frac{1}{2}$ t Fall During a Recession", Harvard University Press, Cambridge.

[15] Blanchard, O. and Galí, J., 2007. "Real Wage Rigidities and the New Keynesian Model," Journal of Money, Credit and Banking, Blackwell Publishing, vol. 39(1).

[16] Blanchard, O. and Kahn, C. M., 1980. "The Solution of Linear Difference Models under Rational Expectations," Econometrica, Econometric Society, vol. 48(5).

[17] Bodart, V., Pierrard, O., and Sneessens, H. R., 2006. "Calvo Wages in a Search Unemployment Model," IZA Discussion Papers 2521, Institute for the Study of Labor (IZA).

[18] Brulhart, M. and Trionfetti, F., 2004. "Public expenditure, international specialisation and agglomeration," European Economic Review, Elsevier, vol. 48(4).

[19] Calvo, G., 1983. "Staggered Prices in a Utility Maximizing Framework," Journal of Monetary Economics, vol. 12.

[20] Campolmi, A. and Faia, E., 2006. "Cyclical inflation divergence and different labor market institutions in the EMU," Working Paper Series 619, European Central Bank.

[21] Canzoneri, M. B., 2007. "Coordination Of Monetary And Fiscal Policy In A Monetary Union: Policy Issues And Analytical Models," Manchester School, University of Manchester, vol. 75(1). 
[22] Christiano, L. J., Eichenbaum, M., and Evans, C. L., 2005. "Nominal Rigidities and the Dynamic Effects of a Shock to Monetary Policy," Journal of Political Economy, University of Chicago Press, vol. 113(1).

[23] Chari, V.V., Kehoe, P.J., 1999. "Optimal fiscal and monetary policy. In: Taylor, J.B., Woodford, M. (Eds.), Handbook of Macroeconomics, vol. 1C. Elsevier Science, North-Holland.

[24] Christoffel, K. and Linzert, T., 2005. "The role of real wage rigidity and labor market frictions for unemployment and inflation dynamics," Working Paper Series 556, European Central Bank.

[25] Clarida, R., Galí, J. and Gertler, M., 1999, "The Science of Monetary Policy: A New Keynesian Perspective", Journal of Economic Literature, Vol. 37.

[26] Corsetti, G. and Pesenti, P., 2001. "Welfare and macroeconomic interdependence," Quarterly Journal of Economics, Vol. 116.

[27] Devicienti, F., Maida, A. and Sestito, P., 2007. "Downward Wage Rigidity in Italy: Micro-Based Measures and Implications," Economic Journal, Royal Economic Society, vol. 117(524).

[28] Dickens, W. T., Goette, L., Groshen, E. L., Holden, S., Messina, J., Schweitzer, M. E., Turunen, J., and Ward, M. E. 2007. "How Wages Change: Micro Evidence from the International Wage Flexibility Project," Journal of Economic Perspectives, American Economic Association, vol. 21(2).

[29] Duarte, M. and Wolman, A. L., 2008. "Fiscal policy and regional inflation in a currency union," Journal of International Economics, Elsevier, vol. 74(2), pages 384-401, March.

[30] Du Caju, P., Fuss, C. and Wintr, L., 2007. "Downward wage rigidity for different workers and firms - an evaluation for Belgium using the IWFP procedure," Working Paper Series 840, European Central Bank.

[31] Erceg, C. J., Henderson, D. W., and Levin, A., 2000. "Optimal monetary policy with staggered wage and price contracts," Journal of Monetary Economics, Elsevier, vol. $46(2)$. 
[32] Faia, E., 2008. "Optimal monetary policy rules with labor market frictions," Journal of Economic Dynamics and Control, Elsevier, vol. 32(5).

[33] Ferrero, A., 2007. "Fiscal and Monetary Rules for a Currency Union," mimeo, Federal Reserve Bank of New York, NYC.

[34] Ferrero, A., 2009. "Fiscal and Monetary Rules for a Currency Union," Journal of International Economics, 77 (1).

[35] Forlati, C., 2008. "Optimal Monetary Policy in the EMU: Does Fiscal Policy Coordination Matter?", mimeo, Universitat Pompeu Fabra.

[36] Galí, J., Gertler, M., and Lopez-Salido, J., 2005. "Robustness of the estimates of the hybrid New Keynesian Phillips curve," Journal of Monetary Economics, Elsevier, vol. $52(6)$.

[37] Gali, J., Gertler, M., 1999. "Inflation dynamics: A structural econometric analysis," Journal of Monetary Economics, Elsevier, vol. 44(2).

[38] Galí, J. and Gertler, M., and Lopez-Salido, J., 2001. "European inflation dynamics," European Economic Review, Elsevier, vol. 45(7).

[39] Galí, J.,Gertler, M. and Lopez-Salido, D., 2003. Erratum to "European inflation dynamics," European Economic Review, Elsevier, vol. 47(4).

[40] Galí, J., Monacelli, T., 2008. "Optimal Monetary and Fiscal Policy in a Currency Union," Journal of International Economics, forthcoming.

[41] Galí, J., 2008. "Monetary Policy, Inflation, and the Business Cycle," Priceton University Press.

[42] Galí, J. and Monacelli, T., 2005. "Monetary Policy and Exchange Rate Volatility in a Small Open Economy," Review of Economic Studies, Blackwell Publishing, vol. $72(3)$.

[43] Gertler, M. and Leahy, J., 2006. "A Phillips Curve with an Ss Foundation," NBER Working Papers 11971, National Bureau of Economic Research, Inc.

[44] Hall, R., 2005. "Employment Fluctuations with Equilibrium Wage Stickiness," American Economic Review, American Economic Association, vol. 95(1). 
[45] Heckel, T., Le Bihan, H. and Montornés, J., 2008. "Sticky wages. Evidence from quarterly microeconomic data," Working Paper Series 893, European Central Bank.

[46] Holden, S. and Wulfsberg, F., 2007. "Are Real Wages Rigid Downwards?, CESifo Working Paper Series CESifo Working Paper No. 1983, CESifo GmbH.

[47] Ireland, P., 2004. "Money's role in the monetary business cycle," Journal of Money, Credit and Banking vol. 36 .

[48] Klein, P., 2000. "Using the generalized Schur form to solve a multivariate linear rational expectations model," Journal of Economic Dynamics and Control, Elsevier, vol. 24(10).

[49] Krause, M. U. and Lubik, T. A., 2007. "The (ir)relevance of real wage rigidity in the New Keynesian model with search frictions," Journal of Monetary Economics, Elsevier, vol. 54(3).

[50] Lindé, J., 2005. "Estimating New-Keynesian Phillips curves: A full information maximum likelihood approach," Journal of Monetary Economics, Elsevier, vol. 52(6).

[51] Leith, C. and Wren-Lewis, S., 2008. "Interactions between monetary and fiscal policy under flexible exchange rates," Journal of Economic Dynamics and Control, Elsevier, vol. $32(9)$.

[52] Lombardo, G. and Sutherland, A., 2004. "Monetary and fiscal interactions in open economies," Journal of Macroeconomics, Elsevier, vol. 26(2).

[53] Malley, J., Philippopoulos, A. and Woitek, U., 2007. "To React or Not? Fiscal Policy, Volatility and Welfare in the EU-3," IEW - Working Papers iewwp312, Institute for Empirical Research in Economics - IEW.

[55] Mehrmann, V., 2007. "Numerical Methods for Eigenvalue and Control Problems", in Frontiers in Numerical Analysis, edited by Blowey, J., 2007, Springer, Berlin, Heidelberg, New York.

[55] Meyer-Gohde, A., 2007. "Solving Linear Rational Expectations Models with Lagged Expectations Quickly and Easily," SFB 649 Discussion Papers SFB649DP2007-069, Sonderforschungsbereich 649, Humboldt Universitï $; \frac{1}{2}$ t. 
[56] Mortensen, D. and Nagypál, E., 2007. "More on Unemployment and Vacancy Fluctuations," Review of Economic Dynamics, Elsevier for the Society for Economic Dynamics, vol. 10(3).

[57] Rotemberg, J., and Woodford, M., 1997, "An Optimization-Based Econometric Framework for the Evaluation of Monetary Policy," in Bernanke and Rotemberg (eds.), NBER Macroeconomic Annual 1997, Cambridge, MA: MIT Press.

[58] Rudd, J., and Whelan, K., 2005. "New tests of the new-Keynesian Phillips curve," Journal of Monetary Economics, Elsevier, vol. 52(6).

[61] Sbordone, A., 2005. "Do expected future marginal costs drive inflation dynamics?," Journal of Monetary Economics, Elsevier, vol. 52(6).

[60] Schmitt-Grohé, S. and Uribe, M., 2004. "Optimal fiscal and monetary policy under sticky prices," Journal of Economic Theory vol. 114.

[61] Shimer, R., 2005. "The Cyclical Behavior of Equilibrium Unemployment and Vacancies," American Economic Review 95(1).

[62] Smets, F. and Wouters, R., 2003. "An Estimated Dynamic Stochastic General Equilibrium Model of the Euro Area," Journal of the European Economic Association, MIT Press, vol. 1(5).

[63] Svensson, L. E., 2004. "Targeting Rules vs. Instrument Rules for Monetary Policy: What is Wrong with McCallum and Nelson?," NBER Working Papers 10747, National Bureau of Economic Research, Inc.

[64] Svensson, L. E., 2003. "What Is Wrong with Taylor Rules? Using Judgment in Monetary Policy through Targeting Rules," Journal of Economic Literature, American Economic Association, vol. 41(2).

[65] Uhlig, H., 1995. "A Toolkit for Analyzing Nonlinear Dynamic Stochastic Models easily", in Computational Methods for the Studies of Dynamic Economies, edited by Ramon Marimon and Andrew Scott, Oxford University Press 1999.

[66] Uhlig, H., 2007. "Explaining Asset Prices with External Habits and Wage Rigidities in a DSGE Model," American Economic Review, American Economic Association, vol. $97(2)$. 
[67] Wolfstetter, E., 2002. "Topics in Microeconomics - Industrial Organization, Auctions and Incentives", Cambridge University Press.

[68] Woodford, M., 2003. "Interest and Prices: Foundations of a Theory of Monetary Policy", Princeton University Press.

[69] Woodford, M., 2002, "Infation Stabilization and Welfare," Contributions to Macroeconomics 2(1), Article 1. 